\title{
POLÍTICA Y CORRUPCIÓN EN LA CORTE ISABELINA. EL ASCENSO DEL «CLAN DE TARANCÓN»
}

\author{
Cristina Bienvenida Martínez García \\ (Universidad Rey Juan Carlos) \\ cristinab.martinezg@urjc.es
}

\section{RESUMEN}

A comienzos del siglo XIX se consumó el cambio de las estructuras del Estado y de la sociedad en España. Aunque el nuevo Estado gobernó con igualdad, a través de sus instituciones, a toda la sociedad, en la práctica no desaparecieron las formas y métodos del gobierno cortesano, basados en las relaciones no institucionales (familiares, patronazgo, clientelismo, etc.). En el nuevo Estado, este comportamiento, es parte importante de lo que constituye la corrupción. Este artículo profundiza sobre cómo la familia de Fernando Muñoz utilizó la relación que tenía con la reina Isabel II para conseguir títulos y negocios, que le llevaron a introducirse en la alta burguesía de la sociedad española del siglo XIX y en los partidos políticos.

PALABRAS CLAVE: siglo XIX; Fernando Muñoz; corrupción; clientelismo; «clan de Tarancón».

\section{POLITICS AND CORRUPTION IN THE ISABELINE COURT. THE RISE OF THE «CLAN OF TARANCÓN»}

\begin{abstract}
At the beginning of the 19th century, the change in the structures of the State and society in Spain was consummated. Although the new State governed with equality, through its institutions, the entire society, in practice the forms and methods of court government, based on non-institutional relationships (family, patronage, patronage, etc.) did not disappear. In the new state, this behaviour is an important part of what constitutes corruption. This article delves into how the family of Fernando Muñoz used the relationship it had with Queen Isabel II to obtain titles and businesses, which led him to enter the upper bourgeoisie of 19th century Spanish society and political parties.
\end{abstract}

KEY WORDS: XIX Century; Fernando Muñoz; corruption; patronage; "Clan de Tarancón”. 
Durante la primera mitad del siglo XIX se produjo en Europa el ascenso de la burguesía. Si las revoluciones burguesas consiguieron establecer la igualdad de derechos a todos los ciudadanos en el nuevo Estado liberal, el dinero fue el criterio de la articulación social y las claves en el éxito económico se cifraban en el individualismo y en el utilitarismo ${ }^{1}$. El liberalismo era igualitario, defendía los mismos derechos y oportunidades para todos los individuos, pero tales ideas chocaban con la desigualdad social y económica existentes; por consiguiente, mientras unos ideólogos comenzaron a poner en duda el derecho a la propiedad, otros recurrieron a la teoría de las facultades y de los instintos, que cada persona posee, para justificar la manifiesta desigualdad social ${ }^{2}$. Por consiguiente, los burgueses consiguieron su hegemonía a través del poder económico, pero también necesitaron la ayuda del poder político, de ahí, que buscasen ocupar los principales cargos del Estado con el fin de asegurarse el éxito en sus negocios, buena parte de ellos, relacionados con las infraestructuras del nuevo Estado liberal (minas, carreteras, puertos, ferrocarriles) ${ }^{3}$, lo que significó la aparición de redes o grupos de personajes que se regían por relaciones de amistad o clientelismo (propias de las "Monarquías cortesanas" anteriores), pero no por las leyes igualitarias e instituciones que proclamaba el nuevo régimen político ${ }^{4}$. Es decir, que aunque los liberales predicasen que el Estado se estructuraba por instituciones y se regía por leyes universales, la práctica política aún se articulaba según el "sistema de la corte" (cuando el rey era el fundamento de la Monarquía), esto es, a través de relaciones personales (patronazgo, clientelismo, parentesco, etc. ${ }^{5}$. La articulación del relato histórico para explicar la evolución de la nación a través de las instituciones, no se correspondían en nada con las verdaderas causas que empujaban a la sociedad y el desarrollo de la

${ }^{1}$ Josep María Fradera, Las burguesías europeas del siglo XIX: sociedad civil, política y cultura (Valencia: Biblioteca Nueva, Universitat de Valencia, 2000). Giovanni Levi, "Prólogo: familias, jerarquización y movilidad social. Nuevas perspectivas", en Familias, jerarquización y movilidad social (Murcia: Universidad de Murcia, 2010), 9-19.

2 Álvaro Flórez Estrada, La cuestión social (Madrid: Imprenta de Don Miguel de Burgos, 1839), no veía legitimado el derecho a la propiedad; por su parte, Ramón de la Sagra, Lecciones de economía social dadas en el Ateneo científico de Madrid (Madrid: Imprenta de Ferrer y Compañía, 1840), se levantaba contra el trabajo de Flórez, al igual que Ruperto Navarro Zamorano, Curso de Derecho natural de Abrens (Madrid: Boix, 1841), quien utilizaba frases muy duras contra Flórez en el Apéndice I. Resume la polémica con gran precisión, Eloy Terrón, Sociedad e Ideología en los orígenes de la España Contemporánea (Barcelona: Península, 1969), 165.

${ }^{3}$ Gabriel Tortella Casares, Los orígenes del capitalismo de España: banca, industria y ferrocarriles en el siglo XIX (Madrid: Tecnos, 1973), 19-48. Antonio Gómez Mendoza, Ferrocarril, Industria y mercado en la modernización de España (Madrid: Espasa Calpe, 1989). Rafael Zurita Aldeguer, "La representación política en la formación del Estado español (1837-1890)", en Estado y periferias en la España del siglo XIX, ed. Salvador Calatayud Giner (Valencia: PUV, 2009), 159-183. José Antonio Piqueras, "Negocios y política en el siglo XIX español", en Javier Paniagua y José Antonio Piqueras (eds.), Poder económico y poder politico (Valencia: Centro Francisco Tomás y Valiente-UNED-Fundación Instituto Historia Social, 1998), 1152.

${ }^{4}$ José Ramón Urquijo Goitia, Gobierno y ministros españoles en la Edad Contemporánea (Madrid: CSIC 2008), 33-40.

${ }^{5}$ Sobre la articulación del sistema de corte y su descomposición, José Martínez Millán y David Quiles Albero, "Introducción", en Crisis y descomposición del sistema cortesano, eds. José Martínez Millán y David Quiles Albero (Madrid: Polifemo, 2020), 1-10. 
política. Los diferentes grupos sociales utilizaban las instituciones (en las que residía la soberanía nacional) para conseguir sus intereses particulares para lo que utilizaron diversas formas de coalición ${ }^{6}$. Ahora bien, semejante forma de actuación fue considerada "corrupción". La corrupción se produjo en amplios sectores políticos y sociales, por lo que llegó a ser considerada como una categoría analítica predefinida para su utilización para el análisis histórico.

El primer problema que se planteó en esta clase de historia fue buscar una definición del término "corrupción”, lo que arrastró a una amplia discusión entre los científicos sociales: politólogos, economistas y sociólogos ${ }^{7}$. Pues, si se percibe con claridad lo que es "corrupción", resultó difícil definirla, por lo que los numerosos ensayos que aparecieron sobre el tema ${ }^{8}$, indujeron a estudiarla de manera inversa, es decir, que para concretar el concepto era necesario "historizarlo" ". El consenso científico actual tiende a ver en la corrupción uno de los conceptos fundamentales de nuestras modernidades políticas:

En otras palabras, uno de los postulados de las investigaciones recientes es considerar

\footnotetext{
${ }^{6}$ María Zozaya Montes, El casino de Madrid: ocio, sociabilidad, identidad y representación social, Tesis doctoral (UCM, 2008). Francisco Villacorta Ramos, El Ateneo Cientifico, Literario y Artístico de Madrid, 1885-1912 (Madrid: CSIC, 1985). Id., "Los Ateneos liberales: política, cultura y sociabilidad intelectual", Hispania 63/2 (2003): 415-444. Rafael María Labra Cadrana, El Ateneo de Madrid: sus orígenesdesenvolvimiento, representación y provenir (Madrid: Imprenta Aurelio Alaria, 1878).

${ }^{7}$ Mark J. Farrales, "What is Corruption? A History of Corruption Studies and the Great Definitions Debate", SSRN (2005): 1-50. Jens Ivo Engels, "De lo antiguo a lo nuevo. La historia de la corrupción política en Europa. Estado de la cuestión y debates actuales de investigación”, en La corrupción politica en la España Contemporánea, eds. Borja de Riquer et al. (Madrid: Marcial Pons, 2019), 25-46. Xavier Forcadell i Esteller, "La corrupción en los gobiernos y administraciones locales en la España Contemporánea", en La corrupción política en la España Contemporánea, eds. Borja de Riquer et al. (Madrid: Marcial Pons, 2019), 332-335. Oriol Luján, "En reconnaissant la corruption. La dénonciation des pratiques immorales pendant la consolidation du système parlementaire espagnol (1834-1868)", en Cesare Martina et al. (dirs.), Dénoncer la corruption. Chevaliers blancs, pamphlétaires et prometeurs de la transparence à l'époque contemporaine (Paris: Demopolis, 2018), 75-93. Peter Eigen, Las redes de corrupción. La sociedad civil contra los abusos de poder (Barcelona: Ediciones del Bronce, 2004).

${ }^{8}$ Realizan un breve resumen de la evolución del concepto corrupción, que resulta muy ilustrativo: Borja de Riquer, Gemma Rubí y Lluís Ferrán Toledano, "Más allá del escándalo. La historia de la corrupción política en la España contemporánea”, en La corrupción política en la España Contemporánea, eds. Borja de Riquer et al. (Madrid: Marcial Pons, 2019), 50-53.

${ }^{9}$ Con este motivo surgieron una gran cantidad de estudios, valga mencionar, Bruce Buchan, Lisa Hill, An Intellectual History of political Corruption (London: Palgrave-Macmillan, 2014). Jens Ivo Engels, Frédéric Monier, Natalie Petiteau, La politique vue d'en bas. Pratiques privées et débats publics, 19e-20e siècles (actes du colloque d'Avignon, mai 2010) (Paris: Armand Colin, 2012), tomo 1. Frédéric Mornier, Jens Ivo Engels y Olivier Dard (Coords.), Patronage et corruption politiques dans l'Europe Contemporaine (Paris: Armand Colin, 2014), tomo 2; dentro de la historiografía española también ha sido un tema de interés en los últimos años, desde los primeros trabajos de Juan Pro Ruiz, "Poder político y poder económico en Madrid de los moderados (1844-1854)", Ayer 66 (2007): 27-55. Id., "El Estado grande de los Moderados en la España del siglo XIX”, Historia y Política 36 (2016): 19-48. Hasta los más recientes como los colectivos, coordinados por Borja de Riquer et al. (eds.), La corrupción política en la España contemporánea. Un enfoque interdisciplinar (Madrid: Marcial Pons, 2019) o los aportados en los dossiers de las revistas Historia y Politica (2018) y Ayer (2019).
} 
la cuestión de la corrupción como una puerta de entrada para comprender mejor las prácticas de influencia y las técnicas de la micropolítica, pero también los sistemas de normas y los debates públicos en todas sus formas ${ }^{10}$.

Esta novedad de planteamiento historiográfico de investigación ha llevado, incluso, a analizar determinadas prácticas consentidas por los monarcas durante la Edad Moderna, como la "venta de cargos", que por considerarlas en la actualidad corruptas, dado el fundamento y justificación político del Estado liberal, no parece que tuvieran el mismo significado en los siglos XVI-XVIII ${ }^{11}$.

El problema se entiende mejor desde los planteamientos de Pierre Bourdieu, quien afirmaba que el rey y la familia real (desde la baja Edad Media) perpetuaron un modelo de reproducción de tipo doméstico, de base familiar, que trasmitían el patrimonio de padres a hijos. Su objetivo era perpetuar la "familia" en el tiempo, de ahí, la constitución de la "casa" o "dinastía"; ahora bien, para llevar a cabo esta "institucionalización de la familia" era necesario la implantación de otro modo de organización: el modo de administración de los funcionarios, que pasaba por aprender sus saberes en el sistema académico. Desde muy temprano, los primeros letrados fueron licenciados en leyes, que pudieron invocar su competencia contra determinadas decisiones de la autoridad dinástica. Algunos economistas modernos han visto este tipo de organización en las empresas actuales en las que se distinguen con claridad los propietarios y los administradores, pero en la realidad, quienes actúan como auténticos dueños de la empresa son los administradores, incluso, a la hora de tomar decisiones importantes ${ }^{12}$. Tenemos, pues, de un lado, los herederos cuyo poder reposa en el principio dinástico de la sangre, y del otro, a los administradores (letrados), es decir, los que para asentar su autoridad deben invocar otros principios de autoridad, a saber, el mérito y la competencia. Es decir, para defender el principio dinástico, los reyes estaban obligados a apoyarse en aquellos servidores cuya existencia reposaba en un principio no dinástico ${ }^{13}$. Por consiguiente, tras las revoluciones burguesas, el tema de

${ }^{10}$ Gemma Rubí y Frédéric Monier, “Presentación. Los favores y los sermones”, Ayer 115 (2019): 15.

11 Así parece interpretarlo Gemma Rubí y Frédéric Monier, "La corrupción general del siglo. Palabras y discursos sobre la corrupción política en la España del siglo XIX”, Ayer 115 (2019): 132, para lo que recurren a los trabajos del profesor Francisco Andújar que, si constituyen un análisis riguroso desde el punto de vista social, en mi opinión, no encajan con lo que entendemos por "corrupción". Estoy con la opinión de Engels, "De lo antiguo a lo nuevo", 25-26, quien también lo niega. Los trabajos a los que me refiero, Francisco Andújar y María Mar Felices de la Fuente (eds.), Elpoder del dinero. Venta de cargos y honores en el Antiguo Régimen (Madrid: Biblioteca Nueva, 2016). Pilar Ponce Leiva y Francisco Andújar (eds.), Mérito, venalidad y corrupción en España y América. Siglos XVII y XVIII (Valencia: Albatros, 2016).

${ }^{12}$ La teoría de la separación entre propietarios y administradores fue expuesta por dos economistas americanos haciendo su estudio sobre grandes empresas: Adolf Berle y Gardiner Means, The Modern Corporation and Private Property (New York: Transaction Publishers, 1933), en el que concluían que realmente los administradores se comportaban como auténticos propietarios de la empresa.

${ }^{13}$ Sobre el tema, Pierre Bourdieu, "Les juristes, gardiens de l'hypocrisie collective", en Normes juridiques et régulations sociale, eds. François Chazel y Jacques Commaille (Paris: LGDJ, 1991), 95-99. 
la corrupción siempre ha ido unido a la utilización particularista de las instituciones del Estado (soberanía nacional) ${ }^{14}$.

Ahora bien, la corrupción lleva unido también otro aspecto que con frecuencia se confunde o identifica, me refiero al tema del "escándalo". La historiografía sobre el tema ha sido muy extensa en España ${ }^{15}$. La profesora Isabel Burdiel ha sido una de las que mejor ha tratado este tema ${ }^{16}$. El "escándalo" surgió cuando se había formado la "opinión pública" durante el siglo XVIII. Ya desde la segunda mitad del siglo XVII, los clubs literarios, academias, casas de té, logias masónicas y, en general, todos los organismos que formaron la denominada "República de las Letras"17, contribuyeron al intercambio social y cultural al margen de las deliberaciones y órdenes que se impartían en las instituciones y en el ámbito de la Iglesia ${ }^{18}$. Ello dio lugar a la aparición de una opinión distinta a la de las instituciones oficiales, pero que era respetada por la sociedad: la opinión pública.

Locke fue el padre espiritual de la Ilustración burguesa ${ }^{19}$. Locke distinguía tres clases de leyes: la ley divina, que es predicada por la naturaleza y la Revelación; la ley civil, es la ley del Estado, vinculada al poder coactivo y la ley moral específica. Las leyes morales burguesas surgen en el ámbito interior de la conciencia humana. Aunque los ciudadanos habían depositado en manos del Estado la plena disposición de sus propios

\footnotetext{
${ }^{14}$ Gemma Rubí y Lluís Ferran Toledano, "La corrupción del siglo. Palabras y discursos sobre la corrupción política en la España del siglo XIX”, Ayer 115 (2019): 131-157. Jesús Cruz, "Lealtad y meritocracia: ambivalencias entre el discurso público y práctica privada de las elites ilustradas y liberales españolas", Historia social 23 (1995): 65-101.

15 Olivier Dard et al. (eds.), Scandales et corruption à l'époque contemporaine (Paris: Armand Colin, 2014).

${ }^{16}$ Isabel Burdiel, "La revolución del pudor: escándalos, género y política en la crisis de la Monarquía liberal en España”, Historia y Política 39 (2018): 23-51; Isabel Burdiel, Los Borbones en pelota (Zaragoza: Institución Fernando el Católico, 2012). Pol Dalmau, "La reputación del notable. Escándalos y capital simbólico en la España liberal”, Historia y Política 39 (2018): 79-107. Marie Angèle Orobón, "Una gloriosa revolución: prensa satírica ilustrada y afirmación militante (1868-1870)", en La historia, lost in translation? Actas del XIII Congreso de la Asociación de Historia Contemporánea, eds. Alberto González Madrid, Manuel Ortíz Heras y Juan Sisinio Pérez Garzón (Cuenca: Universidad de Castilla La Mancha, 2017), 10651075; José Peris y Valero, El proceso de los Borbones (Madrid: Imprenta de la Regeneración, 1856). Josep Pich, "La Gloriosa y la radicalización de la sátira. Tomás Padró, La Flaca y la cultura política republicana", en La historia, lost in translation? Actas del XIII Congreso de la Asociación de Historia Contemporánea, eds. Alberto González Madrid, Manuel Ortíz Heras y Juan Sisinio Pérez Garzón (Cuenca: Universidad de Castilla La Mancha, 2017), 1077-1089. John B. Thompson, "Los escándalos sexuales en la esfera política”, en El escándalo político. Poder y visibilidad en la era de los medios de comunicación, ed. John B. Thompson (Barcelona: Paidós, 2001), 167-218.

${ }^{17}$ Daniel Roche, Les Républicains des lettres: Gens de culture et lumières au XVIIIe siècle (Paris: Fayard 1988). Margaret C. Jacob, The Radical Enlightenment: Pantheist, Freemasons and Republicans (London: Allen \& Unwin, 1981). Dena Goodman, The Republic of the Letters. A Cultural History of the French Enlightenment (Ithaca, New York: Cornell University Press, 1994). Hans Bots y François Waquet, La Reppublica delle lettere (Bologna: Il Mulino, 2005), 11-12. Reinhart Koselleck, Crítica y crisis del mundo burgués (Madrid: Rialp, 1965), 25.

${ }^{18}$ Jürgen Habermas, Historia y crítica de la opinión pública, la transformación estructural de la vida pública (Barcelona: Gustavo Gili, 1981), 25-38. Georges Gurtvich, Essais de sociologie: les formes de la sociabilité. Le problème de la conscience collective (Paris: Librairie du Recueil Sirey, 1938).

${ }^{19}$ Crawford Brough Macpherson, La teoría politica del individualismo posesivo. De Hobbes a Locke (Madrid: Trotta, 1979).
} 
poderes, de manera que no podían proceder ya contra ningún conciudadano, poseían y conservaban el poder espiritual del juicio moral. Son los ciudadanos quienes establecen libremente, mediante su aprobación o su rechazo, lo que debe ser considerado como virtud y lo que no debe ser estimado por tal. Las opiniones de los ciudadanos sobre la virtud y el vicio no permanecen ya dentro del campo de las creencias y pareceres privados; por el contrario, los juicios morales de los ciudadanos poseen de por sí un carácter de ley ${ }^{20}$.

Lo ha explicado con claridad Koselleck; sin autorización estatal, las leyes de la moral burguesa sólo subsisten, pero ya no están limitadas a los individuos en cuanto tales, sino que reciben su obligatoriedad general del tácito y secreto acuerdo de todos los ciudadanos. El formulador de la moral secreta no es ya el individuo, sino la sociedad. Los ciudadanos no quedan ya subordinados exclusivamente al poder estatal, sino que constituyen conjuntamente una sociedad que desarrolla sus propias leyes morales, leyes que aparecen junto a las leyes del Estado. Con ello, la moral burguesa penetra en el ámbito de la vida pública; las leyes morales burguesas no están ya reducidas al campo de la convicción o las creencias, sino que determinan la moral de las acciones. Los ciudadanos establecen ahora el valor de cada acción. Pero no es ya el soberano quien decide; los ciudadanos son ahora quienes constituyen las leyes morales mediante su veredicto. Las opiniones privadas de los ciudadanos se elevan a la categoría de ley en virtud de la capacidad de censura que les es propia a éstos. El ámbito privado y el público se excluyen entre sí tanto cuanto éste emana de aquél. Las leyes estatales actúan directamente mediante el poder coactivo del Estado, que se alza detrás de ellas y las respalda; la legislación moral alcanza su eficacia en el mismo Estado, pero de modo indirecto. La moral burguesa se convierte en un poder público, pero en sus consecuencias y repercusión es de carácter político, por cuanto que fuerza a los ciudadanos a adecuar sus acciones no solo a las leyes del Estado, sino también y sobre todo a la ley de la pública opinión. Con ello se creó un nuevo acceso a la diferenciación crítica entre moral y política ${ }^{21}$. La esfera pública de Habermas es un espacio, similar al análogo concepto kantiano, en que los hombres pueden huir de su papel de súbditos, ejercitando e intercambiando opiniones e ideas. Habermas releía la cultura ilustrada como un mundo en que el conocimiento conservaba la potencialidad de emanciparse a través de la crítica. Al mismo tiempo les demostraba la posibilidad de un análisis histórico de gran significado moral para el presente ${ }^{22}$.

Por consiguiente, no es lo mismo "corrupción" que "escándalo" político, pues derivan de la infracción de dos principios distintos, la soberanía nacional y la opinión pública. No todo caso de "escándalo" es "corrupción”, aunque sí toda "corrupción" lleva consigo un acto de "escándalo". Las consecuencias que se derivan de esta

${ }^{20}$ Reinhart Koselleck, Crítica y crisis del mundo burgués (Madrid: Trotta, 1965), 69-98.

${ }^{21}$ Ibid, 78 ss. Roger Chartier, Espacio público y desacralización en el siglo XVIII: los orígenes culturales de la revolución francesa (Barcelona: Gedisa, 1995). Alejandro Sahuí, Razón y espacio público: Arendt, Habermas y Rawls (México: Coyoacán, 2002). Jean-Luc Marais, Les Sociètes d'hommes. Histoire d'une socialité du 18 siècle á nos jours, Anjou, Maine, Touraine (Vauchretien: Ivan Davy, 1986).

${ }^{22}$ Jonathan Israel, La Ilustración radical. La filosofía y la construcción de la modernidad, 1650-1750 (México: FCE, 2012), 25-29. 
aclaración resultan muy importantes para el análisis político, tanto en el siglo XIX como en la actualidad. Dada la amplitud del tema, en este trabajo me limitaré a estudiar la corrupción que practicó el "clan de Tarancón” para ascender socialmente.

\section{LA COMPLICADA ADAPTACIÓN DE LA CORONA A LAS NUEVAS INSTITUCIONES DEL ESTADO. LA NUEVA FUNCIÓN DE LA CASA REAL}

El cambio de estructuras que experimentó la nueva organización Estatal produjo una transformación en la función que iba a desempeñar la Corona y, por consiguiente, también la Casa Real. La Constitución de 1812, al poner la base del Estado en la soberanía nacional de manera tan radical, había despojado a la Corona de su función esencial que había desempeñado durante los siglos anteriores ${ }^{23}$. Es cierto que tras su retorno en 1814, Fernando VII desmontó la obra de las Cortes, declarando que tanto la Constitución como los Decretos de aquéllas eran «nulos y de ningún valor ni efecto, ahora ni tiempo alguno, como si no hubiesen pasado jamás tales actos» ${ }^{24}$, pero no impidió que se produjera la definitiva separación entre el gobierno de la Real Casa (estructura de gobierno cortesano) y los asuntos del Estado ${ }^{25}$. Por Decreto de 22 de mayo, Fernando VII dispuso que el Mayordomo Mayor ejerciese las funciones gubernativas, tanto relativas a la Real Casa como al Real Patrimonio "separando enteramente el gobierno e interés de mi Real Casa de los demás del Estado". Basándose en Cos-Gayón ${ }^{26}$, Menéndez Rexach afirma que, "la separación entre la Casa Real y la Administración del Estado fue una de las poquísimas reformas que Fernando VII creyó conveniente continuar entre las muchas proclamadas por las Cortes de Cádiz» ${ }^{27}$. Esta misma opinión es ratificada por Moya Valgañón "No sería, precisamente, hasta el Reinado de Fernando VII, cuando se estableciese clara distinción entre el Patrimonio Real y el del Estado"28.

\footnotetext{
23 Joaquín Varela Suances-Carpegna, La Monarquia doceañista (1810-1837). Avatares, encomios y denuestos de una extraña forma de gobierno (Madrid: Marcial Pons, 2013).

24 «Manifiesto del Rey» de 4 de mayo de 1814, en Decretos del Rey don Fernando VII, por don Fermín Martín de Valmaseda (Madrid: en la Imprenta Real, 1818), I, 8.

${ }^{25}$ Fernando Cos-Gayón, Las cuentas de la Casa Real en el Estado. Breves apuntes (Madrid: Imprenta de Miguel Ginesta, 1873).

${ }^{26}$ Fernando Cos-Gayón, Historia jurídica del Patrimonio Real (Madrid: 1881), 150.

27 Ángel Menéndez Rexach, "La separación entre la casa del rey y la administración del Estado (18141820)", Revista de Estudios Políticos 55 (1987): 55-56. Lo han estudiado, especialmente, para el reino de Valencia, Encarna García Monerris y Carmen García Monerris, Las cosas del rey. Historia política de una desavenencia (1808-1874) (Madrid: Akal, 2015). Carmen García Monerris, "Fernando VII y el Real Patrimonio (1814-1820): las raíces de la cuestión patrimonial en el País Valenciano”, Estudis d’Historia Contemporanea del Pais V alenciá 4 (1982): 35-66. Carmen García Monerris y Encarna García Monerris, "La nación y su dominio: el lugar de la corona", Historia Constitucional 5 (2004): 163-166, explican el cambio de sistema y la incorporación de los bienes al patrimonio real.

28 "Manual que comprende todas las propiedades que posee en esta Corte S. M. la Reyna D" Isabel $2^{a}$. Contiene, asimismo, varias otras noticias y observaciones de interés para la Real Casa. Dedicado a S. M. la Reyna Gobernadora, por su muy fiel y reconocido criado Salvador Enrique de Calvet. Año 1836",
} 
Tras la muerte de Fernando VII, aunque se admitió esta distinción entre los bienes de la nación y de la familia real, la Corona buscó los medios para intervenir en el gobierno y seguir manteniendo su influencia directa en la política del nuevo Estado ${ }^{29}$, lo que no resultó fácil. Buena prueba de ello fueron los intentos de establecer una Constitución, en los que el papel reservado a la Corona siempre estuvo presente. Valga recordar que el denominado Estatuto Real de 1834, que en realidad era una "carta otorgada" y que, entre muchas cosas, en ella se establecía que las Cortes sólo podían tratar los temas presentados por la Corona, quien además tenía la potestad exclusiva de convocar y disolver las Cortes ${ }^{30}$. La decepción que provocó los tímidos cambios políticos realizados por Martínez de la Rosa, provocaron en 1836, el motín de la Granja, donde se exigió a la Reina Regente la promulgación de la Constitución de $1812^{31}$. Los progresistas, aprovecharon la situación para iniciar un motín popular en Madrid, que se extendió por la mayor parte de España. Ante estos acontecimientos, la Reina no tuvo más opción que cambiar de jefe de Gobierno y encargó la redacción de una nueva Constitución, la de 1837, en la que se recortaban ciertos privilegios y facultades a la Reina $^{32}$. Como es fácil de suponer, en 1836, quedaban muchas de las formaciones del Antiguo Régimen en Madrid, que fueron variando lentamente y no de manera muy pacífica $^{33}$.

En septiembre de 1840 se produjo un levantamiento, provocado por la Ley de Ayuntamientos, que se inspiraba en criterios centralizadores. La propuso el gabinete Pérez de Castro. Las Cortes la aprobaron en julio, lo que provocó el levantamiento de los grupos progresistas y tras la victoria encumbraron a Espartero a la regencia, ante

Archivo General de Palacio (en adelante AGP), Reinados, Fernando VII, caja 11, exp. 13. José Gabriel Moya Valgañón, "El Patrimonio Nacional. Museos Vividos”, Arbor 665 (2001): 17.

29 "Hubo una trascendental transacción política entre la opinión liberal y los defensores de los derechos dinásticos de Isabel II, que en búsqueda de una fórmula de equilibrio se tradujo en el abandono del modelo constitucional liberal doceañista, con su principio básico de la soberanía nacional, y la adopción del modelo liberal doctrinario, con su alternativo principio sustentador de la doble representación o soberanía compartida, Rey-Cortes, en el que se condensaría el pacto entre la Corona y el partido liberal". Juan Ignacio Marcuello Benedicto, "La práctica del poder moderador de la Corona en la época de Isabel II", Revista de Estudios Politicos 55 (1987): 197-198.

${ }^{30}$ Joaquín Tomás Villarroya, El sistema político del Estatuto Real (Madrid: Instituto de Estudios Políticos, 1968), 45 y ss.

${ }^{31}$ Juan Pro Ruíz, ElEstatuto Realy la Constitución de 1837 (Madrid: Iustel, 2009), 12-59. Joaquín Varela Suances-Carpegna, La Monarquía doceañista (1812-1837) (Madrid: Marcial Pons, 2013). Federico Suárez, Los sucesos de la Granja (Madrid: CSIC, 1953).

32 Jorge Vilches, Progreso y libertad. El partido Progresista en la revolución liberal española (Madrid: Alianza, 2001), 27-30. Joaquín Varela Suances-Carpegna, "La Constitución de 1837: una Constitución transaccional”, Revista de Derecho Público 20 (1983-1984): 95-106. Elías Díaz y Raúl Morodo, “Tendencias y grupos políticos en las Cortes de Cádiz y en las de 1820”, Cuadernos Hispanoamericanos, 201 (1969): 637675. Joaquín Tomás Villarroya, El sistema politico del Estatuto Real (1834-1836) (Madrid: Instituto de Estudios Políticos, 1968). Juan Baró Pazos, "Hacia la consolidación del régimen parlamentario en España: el Congreso de los Diputados en la Constitución de 1837”, Revista de Estudios Políticos 57 (1987): 57-106. Antonio Colomer Viadel, El sistema político de la Constitución española de 1837 (Madrid: Congreso de los Diputados, 1989).

${ }_{33}$ David Ringrose, "Madrid capital imperial", en Madrid. Historia de una capital, eds. Santos Juliá, David Ringrose y Cristina Segura (Madrid: Fundación Caja de Madrid, 1995). 
lo cual, la Regente tuvo que exiliarse a París, pero lo hizo apoyado por una pléyade de moderados. La regencia de Espartero estuvo continuamente hostigada por las conspiraciones de los moderados ${ }^{34}$. Durante el exilio de la Reina Regente, el palacio Courcelles, que María Cristina había comprado en París, se convirtió en centro de maquinaciones. Allí se tramó la confabulación acompañada de Benavides, político moderado, socio del Casino desde el principio ${ }^{35}$. El plan era que destacados militares moderados se encargarían de tomar diversas provincias para instaurar la regencia de María Cristina. Es importante destacar los que se encontraban en Madrid dada la vinculación posterior con Fernando Muñoz: Javier Istúriz era cabeza civil de la rebelión y Diego de León actuaría militarmente, pero junto a ellos estaba Manuel de la Concha, ayudado por Juan Pezuela y los hermanos José y Dámaso Fulgosio. Tras atacar el palacio real, el levantamiento fracasó y, tras severos juicios, fueron fusilados, entre otros, Diego de León y Dámaso Fulgosio. José Fulgosio (que era el encargado de secuestrar materialmente a la reina Isabel cubriéndola con una capa blanca) posteriormente contrajo matrimonio con la hermana de Fernando Muñoz. Asimismo, Nazario Carriquiri también estuvo involucrado el suceso y posteriormente fue socio fiel en materia económica de Muñoz. Como analiza con precisión María Zozaya, el levantamiento estaba organizado por los miembros del Casino ${ }^{36}$.

El regreso de María Cristina propició, con el Partido Moderado, la elaboración de una nueva Constitución. La Constitución de 1845, principio de la soberanía compartida, constituyó la verdadera pieza maestra del modelo constitucional isabelino. El profesor Marcuello la ha reflejado con claridad en el siguiente resumen:

Las leyes fundamentales de la época, una vez declarada la persona del Rey «sagrada e inviolable y no sujeta a responsabilidad», siendo responsables los ministros (art. 42, Constitución de 1845) — lo que implicaba la necesidad del refrendo ministerial a todo lo que «mandare o dispusiese» el Rey «en el ejercicio de su autoridad» (art. 64, ídem)—, hicieron a la Corona residencia del poder ejecutivo (art. 43) y copartícipe en la potestad legislativa, a través de la iniciativa de ley y de la sanción de las leyes con capacidad de veto absoluto e ilimitado (arts. 35, 38 y 44); a la vez que le asignaron tácitamente un poder moderador en el juego político, un poder para arbitrar los conflictos entre los poderes del Estado, que la Corona ejercería a través de las prerrogativas de «nombrar y separar libremente los ministros» (art. 45.10, Constitución de 1845) y de disolver la Cámara electiva, prerrogativa esta última que sólo tendría como limitación la obligación de reunir nuevas Cortes dentro del plazo de tres meses (art. 26) ${ }^{37}$.

\footnotetext{
${ }^{34}$ Luis Garrido Muro, Guerra y Paz. Espartero durante la Regencia de Maria Cristina de Borbón (Madrid: Centro de Estudios Políticos y Constitucionales, 2016), 25-47.

35 Javier Pérez Núñez, "El alzamiento moderado-fuerista de octubre de 1841. El caso de la villa de Bilbao", Hispania 56 (1996): 576. Joaquín Buxó de Abaigar, Domingo Dulce, General Isabelino. Vida y Época (Barcelona: Planeta, 1962), 138.

36 Zozaya Montes, El casino de Madrid, 145.

37 Juan Ignacio Marcuello Benedicto, La práctica parlamentaria en el reinado de Isabel II (Madrid: Congreso de los Diputados, 1986). Id., La Constitución de 1845 (Madrid: Iustel, 2007). Id., "El discurso constituyente y la y la legitimación de la Monarquía de Isabel II en la reforma política de 1845", en Culturas politicas monárquicas en la España liberal. Discursos, representaciones y prácticas (1808-1902) (Valencia: Universitat de Valencia, 2017), 151-176.
} 
La regla de oro de este régimen fue la presunción, por todos los poderes del Estado, de que la instalación y permanencia de un Gobierno en sus funciones dependía de la posesión simultánea tanto de la confianza regia como de la confianza parlamentaria. Este poder permitió a la familia real conformar una red de intereses económicos y políticos, cuyos miembros (políticos y banqueros) sirvieron de aliados y testaferros de la familia real en negocios y monopolios, permitiendo que se convirtiera en una de las más ricas de España ${ }^{38}$.

Así, pues, la Corona había conseguido tener una influencia decisiva en la política del Estado liberal, cuyas funciones quedaban reflejadas en la Constitución; ahora bien, ¿qué sucedió con la Casa Real, organismo fundamental en la configuración política de la Monarquía durante el Antiguo Régimen? Las monarquías europeas de la Edad Moderna articulaban su poder desde la Corte y la Casa Real. Esta organización política estaba fundamentada en la filosofía política clásica (Aristóteles) y se configuraba básicamente a través de relaciones personales en el que la distribución de mercedes se hacía en función del mérito o servicio a la comunidad ${ }^{39}$. La Constitución de 1812 acababa con todo este planteamiento. En el discurso preliminar de presentación del proyecto que habría de convertirse en la Constitución de 1812 se declaraba enfáticamente que:

La falta de conveniente separación entre los fondos que la Nación destinaba para la decorosa manutención del Rey, su familia y casa, y los que señalaba para el servicio público de cada año, o para los gastos extraordinarios que ocurrían imprevistamente, ha sido una de las principales causas de la espantosa confusión que ha habido siempre en la inversión de los caudales públicos. De aquí también la funesta opinión de haberse creído por no pocos y aun intentado sostener como axioma, que las rentas del Estado eran una propiedad del Monarca y su familia ${ }^{40}$.

Desde luego, las Cortes de 1812 en su capítulo V, titulado "De la dotación de la familia real", dejaba bien clara tal distinción. En los nueve artículos que compone dicho capítulo (arts. 213 al 221) se afirmaba reiteradamente que la dotación que se debía dar a la familia real era potestad de las Cortes: "Las Cortes señalarán al Rey la dotación

\footnotetext{
38 Víctor-Manuel Núñez-García, "Las élites en Palacio, la monarquía y la corrupción en la Corte Isabelina”, en Un Rey para la nación. Monarquía y nacionalización en el siglo XIX, ed. Raquel Sánchez (Madrid: Sílex, 2019), 283-311.

39 Antonio M. Hespanha, "Representación dogmática y proyectos de poder", La gracia del Derecho. Economía de la cultura en la Edad Moderna (Madrid: Centro de Estudios Constitucionales, 1993), 61-87, especialmente, 66-68. Daniela Frigo, Il Padre di Famiglia. Governo della casa e governo civile nella tradizione dell'economica tra cinque e seicento (Roma: Bulzoni, 1985), 31 y ss.

${ }^{40}$ Colección de Leyes Fundamentales, ed. de Sainz de Varanda (Zaragoza: 1957), 47. Un análisis de este discurso, en Antonio Fernández García, La Constitución de Cádiæ. (1812) y Discurso preliminar a la Constitución (Madrid: Castalia, 2002). A. Ramos Santana, Constitución política de la Monarquía española, promulgada en Cádiz el 19 de marzo 1812, y Discurso preliminar leido en las Cortes al presentar la Comisión de Constitución el proyecto de ella (Cádiz: Servicio de Publicaciones Universidad de Cádiz, 2010).
} 
anual de su casa, que sea correspondiente a la alta dignidad de su persona" ${ }^{41}$. Seguidamente se definían los bienes que pertenecían al rey: "Pertenecen al Rey todos los palacios reales que han disfrutado sus predecesores, y las Cortes señalarán los terrenos que tengan por convenientes reservar para el recreo de su persona" (art. 214). Asimismo, desgranaban quiénes y cuándo podían disfrutar de la dotación asignada a la casa real, indicando específicamente que "Las Cortes señalarán los alimentos anuales que hayan de darse a la Reina viuda" (art. 218).

En realidad, lo que promulgaban las Cortes de Cádiz con respecto a la organización y gasto de la casa real reflejaba una revolución política en cuanto al significado que tenía la casa y la función que cumplía en la nueva estructura del Estado, que era muy distinta de la función esencial que había mantenido en la articulación política de la Monarquía desde la Baja Edad Media hasta el siglo XVIII. Ahora bien, tan profunda transformación se había producido después de un largo proceso en el que la estructura de la propia casa había ido cambiando paulatinamente hasta adaptarse a la función que iba a tener en la nueva organización política que fue el Estado liberal. La instauración del Estado liberal dejó sin función específica la Casa Real, si bien, ya desde el siglo XVIII (especialmente, desde la reforma que realizó el marqués de La Ensenada en 1749) hubo una serie de transformaciones que descompusieron la Casa Real $^{42}$.

La pérdida de influencia de la Casa Real llevó a una profunda transformación, que consistió en esencia en la simplificación que padeció (desaparición de cargos y creación de otros nuevos, siempre unipersonales) al convertirse de un órgano que estructuraba la administración de la Monarquía a un "simple organismo al servicio del rey". Lejos de perder toda importancia, la Casa Real mantuvo su prestigio e influencia al haber conseguido mantener la Corona su participación en las Cortes y en el gobierno de la nación. Según decreto de 22 mayo 1814 $4^{43}$, Fernando VII organizaba la Casa Real y Patrimonio bajo la figura del mayordomo mayor, al mismo tiempo que desaparecía la Junta de bureo, órgano de gobierno de la Casa Real hasta entonces; las obligaciones de los antiguos oficios de Contralor y Grefier fueron asumidas por la Secretaría de la Mayordomía Mayor y por la Contaduría y Tesorería, y entre las oficinas de la nueva planta figuran la Veeduría general y el Archivo ${ }^{44}$. No resulta pertinente realizar un estudio de las transformaciones experimentadas en la Casa Real durante los primeros cuarenta años del siglo XIX, por otra parte, bien sintetizados por otros historiadores ${ }^{45}$, pero sí considero necesario señalar, por la importancia que dichos cambios tendrán para la formación de la red de Fernando Muñoz, en primer lugar, que la Reina Regente dividió las funciones de la Casa Real en dos secciones muy intencionadas:

${ }^{41}$ Miguel Artola y Rafael Flaquer Montequi, La Constitución de 1812 (Madrid: Iustel, 2008), 107.

42 Martínez Millán y Quiles Albero, "Introducción”, 1-10.

43 AGP. Administración General (AG), leg. 466

44 AGP. Reinados Isabel II, caja 345, exp. 4.

${ }^{45}$ Me remito a la excelente síntesis realizada por: Vanesa Benito et al., "La Jefatura de Oficios y Aposentamiento de la Real Casa y Patrimonio (1814-1931)”, Reales Sitios 174 (2007): 48-64. 
Queriendo yo [Reina gobernadora] que en lo sucesivo corran separadas y ejercidas por distintas personas las funciones de etiqueta y ceremonia de palacio y las económicoadministrativas de la Real Casa, Patrimonio y todas sus dependencias, vengo en decretar lo siguiente: $1^{\circ}$. El Mayordomo mayor, Sumiller de Corps y Caballerizo mayor no tendrán en adelante más facultades ni ejercerán más funciones que las concernientes a la etiqueta, ceremonia y servicio de las Reales Personas, así en la Cámara como fuera de Palacio con sujeción a lo que se estableciere en los reglamentos que para ello se formaren. $2^{\circ}$. De las facciones económico-administrativas se encargará la persona que yo nombrare con título de Intendente general de la Real Casa y Patrimonio. $3^{\circ}$. Con las de igual clase de la Reales Caballerizas y con entera dependencia de aquel, correrá el sujeto que con la denominación de director general de las Reales Caballerizas tuviere yo a bien nombrar.

En segundo lugar, es importante destacar las reformas que se llevaron a cabo en los Reales Sitios y Patrimonio para su explotación económica, en cuyos cargos principales, Fernando Muñoz introdujo a su clientela.

Lógicamente, tanto las reformas en el servicio de la Casa como en los Reales Sitios llevaron consigo la promulgación de numerosos Reglamentos, que controlaban el poder e influencia de los nuevos jefes del servicio de la Casa Real. Tan importante misión fue encargada a José Antonio Muñoz, hermano del esposo de María Cristina de Borbón ${ }^{46}$.

\section{EL “CLAN DE TARANCÓN", UNA RED CLIENTELAR DE ORIGEN HUMILDE}

El tema de los grupos de poder y la importancia que han tenido para explicar la articulación social y su repercusión en las formas de gobierno ha tenido una expansión bibliográfica inmensa en las últimas décadas para explicar la evolución política de las Monarquías. Ello significa que se reconoce la importancia de las relaciones no-institucionales (patronazgo, clientela, familiares, costumbre, etc.) sobre las relaciones institucionales, en las que todos los ciudadanos tienen los mismos derechos, y en donde se valoran el mérito y las aptitudes personales para el ascenso social. Lo sorprendente es que tal clase de relaciones (que reflejan un tipo de gobierno) siempre se ha atribuido al Antiguo Régimen (cuando imperaba el "sistema cortesano" y el "favor" era la forma usual de gobernar); sin embargo, para explicar la trama política

46 "Así mismo adjunto el pliego de las disposiciones generales, entendido con vista de los Reglamentos que rigen, del pliego de anotaciones acordadas por la Junta del proyecto e Instrucción general que he formado en el que trata de la Escala general de ascensos y de honores y distinciones con que pueden ser agraciados los jefes y oficiales de las oficinas generales, los demás altos funcionarios de la Real Casa, Cámara, Capilla, Caballerías y demás jefes, subalternos de los Reales Sitios y patrimonio. Lo complicado y delicado de estos vastos trabajos supera a mis débiles conocimientos por lo que confío en la ilustrada de los miembros de la Junta de Gobierno que suplica los defectos que noten en el desempeño de la comisión con que se dignó honrarme. Acordando, no obstante, mi débil opinión aquello que estimase más conveniente al buen orden de la administración de los Reales intereses. Palacio 31 julio 1838, José Antonio Muñoz” (AGP. AG, leg. 942). 
y el gobierno del Estado liberal, los historiadores se han percatado que las relaciones no institucionales siguieron siendo fundamentales. La bibliografía sobre el tema es abundantísima ${ }^{47}$ (dado el espacio reducido del que dispongo, me impide comentarla) sobre todo desde que los sociólogos explotaron el tema y aplicaron sus métodos de análisis, pero no se interrogaron por los condicionantes políticos ni estructuras y fundamentos del Estado en que se desarrollaban ${ }^{48}$.

El patronazgo social siempre se ha presentado ejercido por una persona con poder. La complejidad social y la diversidad de actividades y la amplitud de competencias del Estado obligaba a que el patrón tuviera que estar personalmente en diferentes actividades o lugares, lo que resultaba imposible, por lo que, el patrón necesitaba de un grupo de poder de confianza en el que sus miembros cumplieran el papel del protector en caso de que éste se viera obligado a participar en varias funciones a la vez ${ }^{49}$. Esto significaba que el vínculo del grupo de poder se establecía entre familias cercanas y personajes del mismo estrato $\operatorname{social}^{50} \mathrm{o}$ de la misma profesión ${ }^{51}$. Las relaciones entre iguales generaban un universo mental y unas aspiraciones que hacían necesario el mantenimiento de unos valores y formas de comportamientos comunes. Esto hacía que una red clientelar fuera coherente y efectiva y a los miembros de estas elites llevaba a una vinculación tan estrecha que, Jeremy Boissevain ${ }^{52}$ ha bautizado como "entre los amigos de los amigos".

No obstante, cuando hablamos de relaciones de patronazgo, nos referimos a las relaciones sociales entre desiguales, que son las que claramente vienen a establecer una relación patrón-cliente. En este caso aparece la figura del broker (intermediario), que resulta esencial para articular la red y para cumplir complejas misiones de relaciones entre el patrón y los clientes ${ }^{53}$. Desde luego, en el caso de Fernando Muñoz,

${ }^{47}$ Es preciso recordar las teorías de Gaetano Mosca y Wilfredo Paretto. Pierre Bourdieu, La distinción (Barcelona: Taurus, 2015). Xosé Veiga, "Los marcos sociales del clientelismo político”, Historia Social 34 (1999): 27-44.

48 Robert Kaufman, "The Patron-Client concept and Macro politics: prospects and problems", Comparative Studies in Society and History 16 (1974): 284-308. Shmuel Noah Eisenstadt y Louise Roniger, "Patron-Client Relations as a Model of Structuring Social Exchange", Studies in Society and History 16 (1980): 42-77.

${ }^{49}$ Félix Requena Santos, Amigos y redes sociales: elementos para una sociología de la amistad (Madrid: Siglo XXI, 1994).

${ }^{50}$ Me refiero, como ejemplo, al banquero y cortesano, fiel isabelino, Nazario Carriquirri, sus amplias relaciones le inclinaron hacia la economía con el también empresario José de Zaragoza y su consecuente círculo; pero también con su entorno político, el diputado y militar Cotoner, Cándido Nocedal, Pérez Vento, quien, a su vez, apadrina a Diego de León, Santos Álvarez o Juan Prim, cuyo brazo derecho y amigo, Milans del Bosch, es introducido en el Casino. Zozaya Montes, El Casino de Madrid, 17-19.

${ }^{51}$ Francisco Villacorta Ramos, Profesionales y burócratas: estado y poder corporativo en la España del siglo XX (1890-1923) (Madrid: Siglo XXI, 1989). Wolfgang Reinhard (Coord.), Las elites de poder y la construcción del Estado (México: FCE, 1996).

52 Jeremy Boissevain, Friends of friend: networks, manipulators and coalitions (Oxford: Basil Brackwell 1978). Félix Requena Santos, "El concepto de red social”, Reis: Revista española de investigaciones sociologicas 48 (1989): 137-152. Id., Amigos y redes sociales.

${ }^{53}$ Estas relaciones fueron bautizadas como "feudalism bastardo" por Kenneth Bruce Macfarlane, "Bastard feudalism", en England in the Fifteenth Century: Collected Essays of Kenneth Bruce Macfarlane (London: 
patrón del "clan de Tarancón", cuyos miembros eran todos de origen social humilde, las relaciones clientelares fueron en su mayoría de esta clase y los brokers desempeñaron un papel fundamental para controlar la administración territorial y la sociedad rural ${ }^{54}$.

\section{a) La utilización de la Casa Real y de los Sitios Reales para la formación de la red clientelar}

Una vez celebrado el matrimonio entre María Cristina de Borbón y Fernando Muñoz, ambos cónyuges mostraron diversas preocupaciones: Fernando Muñoz estaba inquieto por su frágil situación en la corte; no solo tenía en contra a los partidarios de D. Carlos ${ }^{55}$ dado que no tenía partidarios ni amigos, propia de un "hombre nuevo", que ni siquiera tenía un cargo relevante en la administración. Por su parte, María Cristina estaba obsesionada con asentar socialmente su relación y estar a solas con su flamante esposo (a quien irónicamente, en ciertos círculos políticos, comenzaron a llamarle "Fernando VII") ${ }^{56}$ para lo que la corte era el mejor lugar, por lo que proyectó visitar los sitios reales, concretamente se marcharon a Aranjuez y después a san Ildefonso. Evidentemente, los personajes que Fernando Muñoz era capaz de apadrinar (dado que él no era un influyente patrón cortesano) no podían tener rancia genealogía ni elevada posición social, por lo que recurrió a parientes y paisanos suyos (sin duda ninguna, gente en la que se podía fiar) a los que rápidamente comenzó a llamar para concederles oficios mecánicos en palacio o en la administración de los Sitios Reales. La maniobra no pasó desapercibida a los políticos y cortesanos de la época, que vieron cómo el servicio de la casa real se confundió con el trabajo doméstico ya que desconocían los reglamentos y etiquetas de la institución. Fermín Caballero retrataba la situación de la siguiente manera:

Una sensualidad estragada y de baja ralea ha infeccionado los salones de palacio; una familia sin educación ni saber se ha apoderado de la voluntad de la reina, y la camarilla ha degenerado hasta lo más vil y estúpido de la sociedad. La inocente Isabel no sabe ni tiene más maestros a la edad de diez años que de leer y escribir y con el trato y el aprendizaje de los Muñoz habrá de casarse de aquí a dos años ${ }^{57}$.

En efecto, tomando como base los miembros de su familia ${ }^{58}$, Fernando Muñoz se esforzó por articular una facción de fidelidad inquebrantable («clan de Tarancón»)

Hambledon Continuum, 1981), 23-43. Christian Windler, "Mediando relaciones. Redes sociales y cambio político", Hispania 199 (1998): 575-605, da una definición de bróker en 581-582.

${ }^{54}$ Forcadell i Esteller, "La corrupción en los gobiernos", 345-347.

55 Antonio Manuel Moral Roncal, ;El enemigo en Palacio! Afrancesados, liberales y carlistas en la Real Casa y Patrimonio (1814-1843) (Madrid: Universidad de Alcalá de Henares, 2005).

56 Antonio Jiménez Landi, Esos días (Madrid: Aguilar, 1965), 78-87.

${ }^{57}$ Fermín Caballero, La cuestión de la Regencia y el Casamiento de María Cristina de Borbón (Madrid: Imprenta del pueblo soberano, 1840), 22.

${ }^{58}$ Benito Pérez Galdós, Bodas Reales (Madrid: Imprenta de S.M., 1900), 192. «Cuentan que quedó despoblado Tarancón. Los padres viendo tan bien casado al chico no habían de ser tan zotes que desperdiciaran la buena ocasión de colocar a todita la familia. Yo me pongo en su caso. A una hermana, 
que, al mismo tiempo que se enriquecía a través de los sueldos y negocios en los Sitios y la Casa Real, le tuvieran informado de las opiniones que sobre él corrían por la corte. Este grupo fue creciendo a lo largo de la regencia, pues se añadieron no solo nuevos familiares y amigos, sino también conocidos o clientes originarios de pueblos manchegos ${ }^{59}$ en torno a Tarancón, conocidos de la familia. Consciente de las limitaciones de su "clan", Muñoz (siempre con el respaldo de la Reina Regente) introdujo a sus clientes en los cargos de la administración de la casa y en los sitios reales ${ }^{60}$. Para estos cargos no se necesitaba tener grandes títulos ni rancia genealogía como exigían los moderados. A los pocos años, estos mismos personajes comenzaban a ser ascendidos a oficios palatinos, lo que les permitía tener relación con sectores sociales más elevados (cargos altos en la administración o políticos cortesanos) ${ }^{61}$. Es decir, que Fernando Muñoz ponía a sus apadrinados en una ruta que, tras unos pasos sociales lógicos conseguían llegar a lo alto de la sociedad ${ }^{62}$.

El otro gran baluarte de la facción o grupo de Fernando Muñoz fue su pariente don Marcos Aniano González Muñoz nacido en Tarancón, que fue el sacerdote oficiante del matrimonio secreto con María Cristina de Borbón, que fue nombrado capellán de honor de la capilla real, cura de la Parroquia Ministerial del Real Palacio, confesor real de María Cristina de Borbón, Administrador del Buen Suceso, deán de la Habana y prebendado de Lérida ${ }^{63}$.

la Alejandra, la tuvimos de Camarista; á D. José Muñoz, de Contador del Real Patrimonio, y con ellos vino una reata de parientes, amigos y allegados que no se acaba nunca".

${ }^{59}$ Benito Pérez Galdós, Bodas Reales, 176. "Por fin, huroneando entre las viviendas de la servidumbre, encontraron manchegos, que fue para la señora de Carrasco gran satisfacción. ¡Vaya que manchegos en aquellas alturas! Pues en Caballerizas, a donde también fueron como visitantes curiosos, encontró Leandra más de lo que quería: carreristas, picadores y mozos que eran de allá, y hasta parientes le salieron. Bien decía ella que había Mancha en todo el mundo, y que Madrid era lo más manchego de las Españas".

${ }^{60}$ Lo prueba la carta de Fernando Muñoz a Francisco de Asís, marido de la reina Isabel II fechada el 25 noviembre de 1864: "Espero que me perdonará V. M si, aprovechando esta ocasión, molesto su atención entreteniéndolo con un asunto de mi hermano. La mucha bondad que V. M tuvo siempre para conmigo anima a ello. Deseoso, mi hermano, de servir a su Reina en una legación, recomiende a VV. MM. pero yo no quiero nunca molestarle a favor de los de mi familia para empleos del Estado: y así es que los que han servido o sirven lo han hecho siempre en el Real patrimonio gracias a la bondad de $\mathrm{S}$. M. que se sirvió colocarlos". AHN, Diversos títulos_familias, 3563, leg. 27, exp. 71.

${ }^{61}$ Jean-Louis Guereña, "La sociabilidad en la España contemporánea", en Sociabilidad fin de siglo: espacios asociativos en torno a 1898, eds. Rafael Villena Espinosa e Isidro Sánchez Sánchez (Cuenca: Universidad de Castilla La Mancha, 1999), 18-21. Pere Solà y Gussinyer, “Asociacionismo en la España periférica: tipología y rasgos dominantes”, en Asociacionismo en la España contemporánea, vertientes y análisis interdisciplinar, ed. Elena Maza Zorrilla (Valladolid: Universidad de Valladolid, 2003), 90 y ss. Sobre elites, Juan Pro Ruiz, "La formación de la clase política liberal en España (1833-1868)", Historia Contemporánea. Nuevos estudios sobre elites 23 (2001): 445-481. Pedro Carasa Soto, "De la burguesía a las elites, entre la ambigüedad y la renovación conceptual”, Ayer 42 (2001): 225-237.

62 Véase el esquema que realiza Zozaya Montes, El casino de Madrid, 36 sobre lo que representó el Casino de Madrid en el currículum de estos personajes.

${ }^{63}$ AGP, Personal, caja 458, exp. 44. No sólo introdujo en la Corte a Marcos Aniano, sino que su hermana Gregoria fue nombrada camarista para la servidumbre de S.M. el 4 de junio de 1838, AGP, Personal, caja 455, exp. 62. 
Alejandra Muñoz, hermana de Fernando Muñoz, fue introducida en la casa real como camarista de la de la Serma. Sra. Infanta D. Luisa Fernanda ${ }^{64}$. La familia pretendía que alcanzase algún matrimonio ventajoso ${ }^{65}$, anhelo que no consiguió hasta el 30 de octubre 1846, cuando la Reina le concedió "su Real permiso para contraer matrimonio con el excelentísimo general D. José Fulgosio "66".

Otros familiares y amigos: Don Serafín Valero era "hijo del dómine de Tarancón"; Julián Muñoz y Funes tío de Fernando Muñoz, fuenombrado administrador del Real sitio de la Isabela ${ }^{67}$. Juan Gregorio Muñoz Funes, tío de Fernando Muñoz, originario de Tarancón, fue nombrado encargado de negocios en Venezuela $^{68}$. Juan González Cabo-Reluz ${ }^{69}$, natural de Tarancón y primo de Marcos Aniano, se le nombraba bibliotecario $2^{\circ}$ de la biblioteca nacional; poco después, se le nombró preceptor de S.M. y A.R., cargo que ocupó hasta su jubilación ${ }^{70}$. Don Serafín

${ }^{64}$ AGP, Personal, caja 730, exp. 21.

65 Por ello intentaron desposarla con el hermano del Duque de San Carlos: AHN, DiversosTítulos_Familias, 3398, leg. 110, exp. 1.

${ }^{66} \mathrm{Si}$ bien, al principio, el Duque de Riánsares parece se mostró un poco contrario al enlace, dado que no lo consideraba idóneo para el ascenso social de su hermana (AGP, Personal, caja 16933, exp. 21).

66 AGP, Personal, caja 16933, exp. 21.

${ }^{67}$ AGP. Personal, caja 729, exp. 8.

68 AGP. Personal, caja 16517, exp. 1.

${ }^{69}$ Él, al igual que otros miembros pertenecientes a la corte de María Cristina de Borbón como Manuel Dusmet, secretario de la regente María Cristina, tenía un origen marcadamente josefino, como se recoge en el libro Juan López Tabar, Los famosos traidores. Los afrancesados durante la crisis del Antiguo Régimen (1808-1833) (Madrid: Biblioteca Nueva, 2001), 351: "El presidente de la comisión era Juan González Caboreluz, y los demás miembros: García Blanco, Mardones, Aguirre y Landeira. Algunos de ellos eran tachados de Heterodoxos, regalistas y jansenistas. Hasta el punto que puede considerar su ideología y su enseñanza en las cátedras como una de las causas para que los obispos consideraran más conveniente para la iglesia se suprimieran las Facultades".

70 AGP, Personal, caja 462, exp. 13. No cabe duda de que Fernando Muñoz tenía interés en colocar a Coboreluz como ayo de S.M. como muestra esta carta de Salvador Calvet (Secretario oficial mayor de la mayordomía mayor de la Real Casa y Patrimonio) al Duque de Riánsares: "hasta ayer a las ocho de la noche no fue me entregada la favorecida de $\mathrm{V}$ siéndome muy sensible que lo avanzado de la hora me imposibilitase de complacer a $\mathrm{V}$ incluyéndole la orden referente a Caborreluz en los términos que $\mathrm{V}$ me lo pedía. Hágolo ahora de dos iguales con sola la variación de que en la una le doy el dictado de preceptor y en la otra el del Maestro cuyas deferencias voy a explicar brevemente para que mejor informado resuelva S.M. cual de las dos es más conforme a Caborreluz que en mi concepto debe ser en que se le da el dictado de preceptor El Príncipe de Asturias tuvo ayo que siempre ha sido el mayor deseo, y siendo niña la princesa debe tener aya, teniente de Ayo o teniente de Aya que han sido un general a quien se daba la llave de gentil hombre de cámara o de una señora viuda de un general o de algún título que no fuese grande de España. Preceptor que lo fue el obispo de Orihuela y nuestros $\mathrm{V}$ ha crecido que Preceptor y ayo era lo mismo y no es así como tanto demuestra y según lo puede $\mathrm{V}$ ver en los antecedentes que tengo a la vista. Así que Caborreluz debe tener en mi concepto el dictado de preceptor y el sueldo que se le señala, porque si bien es cierto que el preceptor del Príncipe de Asturias tenía sólo 24.000 reales también es cierto que sólo se limitaba su servicio a una sola Persona Real y Caborreluz va a tener a su cuidado dos. Por lo mismo fijé el sueldo que aparece en las órdenes en lo que obré con clero de justicia que se quiere ver ejercido siempre S.M. moviendo personas en este asunto aunque la de que retrata mmi merece la mayor consideración y el más distinguido aprecio. Además salía a la vista que si se le da él dictado de maestro debe ir sucedido de la profesión o de la clase de enseñanza como por 
Valero, hijo del dómine de Tarancón, fue nombrado administrador del Real Sitio de Vista Alegre; también se le nombró administrador y apoderado general de S.A. la Serma. Sra. Infanta $\mathrm{D}^{\mathrm{a}}$ Luisa Fernanda. Finalmente, ascendió a gentilhombre de Cámara $^{71}$. A don Miguel López Acebedo como director de la Casa de la Moneda ${ }^{72}$; a don Antonio García del Castillo, administrador que ha sido de la Casa de Campo y del alcázar de Sevilla. Por su parte, don Rafael Muñoz y Funes, tío de don Fernando Muñoz, fue nombrado rector de la Iglesia de San Pascual en el Real Sitio de Aranjuez y, poco después, teniente de la Real Capilla parroquial de San Antonio de la Florida ${ }^{73}$.

\section{b) La creación del Partido Moderado y el control de las instituciones estatales}

Las instituciones como representación de la soberanía de la nación y su proyección a través de leyes generales impuestas desde la administración fueron los cauces por los que, a partir de las revoluciones burguesas, se ejerció el poder y se gobernó, por lo que los incipientes partidos políticos buscaron el control de las instituciones, mientras la Corona (que no tenía una función clara en esta estructura estatal) se le colocó a la cabeza del Partido Moderado ${ }^{74}$. Como señala el profesor Juan Pro, a quien sigo en estas líneas ${ }^{75}$, los primeros partidos era partidos de notables, se formaban en torno a una afinidad ideológica de sus miembros, pero el reconocimiento de esa afinidad no se hacía en abstracto, sino mediante la adhesión al liderazgo de unas cuantas personalidades célebres que se expresaban en las Cortes y en sus propios medios de prensa; la alianza de estos líderes daba existencia al partido que, por tanto, adoptaba la forma de una red clientelar, cuya fuerza venía determinada por la amplitud de las lealtades que era capaz de movilizar en todo el territorio nacional. Como en todo sistema clientelar, las adhesiones se lograban y mantenían mediante un intercambio de favores, y esto exigía que los líderes políticos pudieran distribuir entre sus seguidores prebendas que les resultaran lo suficientemente atractivas como para otorgar a cambio el apoyo político activo, Fernando Muñoz lo conseguirá respaldado por la autoridad de su esposa. La formación del Partido Moderado fue un proceso complicado: se inició con la aparición de un grupo ministerial más o menos estable en torno a los gabinetes de Martínez de la Rosa, Toreno e Istúriz en la época del Estatuto Real; aquel grupo empezó a tomar consistencia y a adquirir una identidad política más marcada en la

ejemplo maestro de primeras letras, de francés de matemáticas, etc. y chocaría que mientras que los maestros del Príncipe tuvieron doce mil reales se señalasen 40.000 reales de la reina menor, todo está unido a que Caborreluz debe renunciar a la plaza honorífica que tiene de Reales bibliotecas me estimulan a hacer estas cortas reflexiones que no dudo convencerán a $\mathrm{V}$ para que se de a aquel el nombre de preceptor inutilizado la otra orden y avisándomelo para que corran las que se han de pasar a las oficinas de la casa". AHN, Diversos-Títulos_Familias, 3361, leg. 25, exp. 1.

${ }^{71}$ AGP, Personal, caja 1310, exp. 25.

72 AGP, Personal, caja 559, exp. 15.

73 AGP, Personal, caja 729, exp. 9.

74 Francisco Cánovas Sánchez, El Partido Moderado (Madrid: Centro de Estudios Constitucionales, 1982). Fidel Gómez Ochoa, "El liberalismo conservador español del siglo XIX, la formación de una identidad política, 1810-1840", Historia y Política 17 (2007): 37-68.

75 Pro Ruiz, "Poder político y poder económico", 27-55. 
oposición contra Mendizábal y los gobiernos progresistas de los años siguientes; recibió un fuerte impulso de organización y de clarificación ideológica por parte de Andrés Borrego. Pero no terminó de cuajar como fuerza política cohesionada, capaz de afianzarse en el poder de manera estable, hasta 1840-1843, los años del exilio de la reina madre María Cristina en París, en cuyo entorno adquirió el partido su organización definitiva durante los preparativos que condujeron a ambos - María Cristina y los moderados - a recuperar el poder en España. María Zozaya, señala la importancia que tuvo en la formación del partido, el grupo de fundadores del casino de Madrid, que se produjo a raíz del levantamiento de la Granja de 1836. A partir del golpe propiciado por Diego de León y otros militares, todos miembros del casino, y fusilado tras juicio sumario, el Casino tomó un aire anti Espartero y se convirtió en un centro aglutinador de los moderados isabelinos hasta $1854^{76}$.

Fernando Muñoz se encargó de manejar los hilos de la conspiración, tanto en sentido económico, como político y militar, por lo que no resulta exagerado considerarlo el verdadero jefe ejecutivo del Partido Moderado, que por aquellos años era una formación política que se confundía con las camarillas cortesanas ${ }^{77}$. De acuerdo con el papel asignado, no resultó exagerado que Muñoz fuera nombrado (en 1844) Grande de España como duque de Riánsares y que se normalizase su situación oficial como marido de la Reina Madre. Muñoz manejó, desde la época del exilio en París, las relaciones políticas y económicas de María Cristina con ese entorno político. María Cristina suministraba el elemento simbólico que mantenía unidos a los moderados en un contexto de indudable fe monárquica ${ }^{78}$; pero Muñoz era el hombre práctico, dispuesto a involucrarse en los asuntos menudos y a veces turbios que exigía el acontecer diario de la política. El concepto de legitimidad adoptó diferentes significados a lo largo de la centuria y mantuvo estrechos vínculos con el trono. No se puede olvidar que los ritos políticos y simbólicos a los que tuvieron que enfrentarse fueron muy diversos en la legitimidad de la monarquía ${ }^{79}$.

\footnotetext{
76 Zozaya Montes, El casino de Madrid, 133.

77 Ibid., 135 y ss. Pro Ruiz, "Poder político y poder económico”, 27-55.

${ }^{78}$ Ya desde el mismo momento de la regencia, Caballero, La cuestión de la regencia. Manuel Marliani, La Regencia de D. Baldomero Espartero y los sucesos que la prepararon (Madrid: Imprenta de Manuel Galiano, 1870). María Ángeles Casado, "María Cristina de Borbón. Una regente cuestionada", en La imagen del poder. Reyes y regentes en la España del siglo XIX, ed. Emilio La Parra (Madrid: Síntesis, 2001), 133-176. Jesús Sanz Fernández, La sargentada de la Granja. La Granja de San Ildefonso (Madrid: Icaro, 2012). María Ángeles Casado y Mónica Moreno, "María Cristina de Borbón y María Cristina de Habsburgo: dos regentes entre los modos de vida aristocráticos y burgueses", Historia y Política 31 (2014): 113-138.

${ }^{79}$ Sobre este tema, el trabajo pionero de David Cannadine, "Contexto, representación y significado del ritual: la monarquía británica y la intervención de la tradición, c. 1820-1977”, en La invención de la tradición, eds. Eric Hobsbawm y Terence Ranger (Barcelona: Crítica, 2002), 107-171. Para el caso español, véase el reciente estudio de Roberto López Vela, "Una apología de Isabel II desde la familia real", en Crisis y descomposición del sistema cortesano, eds. José Martínez Millán y David Quiles Albero (Madrid: Polifemo, 2020), 503-528. Naiara Pavía Dopazo, "El uso del Exemplum histórico en el debate sobre la monarquía en las Cortes Constituyentes del Bienio Progresista", en El lenguaje político y retórico de las constituciones españolas. Proyectos ideológicos e impacto mediático en el siglo XIX, eds. José Antonio Caballero López, José Miguel Delgado Idarreta y Rebeca Viguera Ruiz (Oviedo: Fundación P. Mateo Sagasta, 2015), 267-287. Aunque ya desde el siglo XIX se intentó hacer un paralelismo con Isabel la Católica,
} 
Un breve análisis de los nombramientos a diputados y miembros del Partido Moderado de los familiares y amigos de Muñoz confirma este proceso: Fernando Agustín Muñoz Sánchez ${ }^{80}$, marido de María Cristina de Borbón, fue nombradosenador de España el 17 de diciembre de 1845. José Antonio Muñoz ${ }^{81}$, hermano de Fernando Muñoz, fue diputado ${ }^{82}$ por la provincia de Cuenca en las legislaturas de "1844 al $45 \mathrm{y}$ del 45 al 46", de 1846 a 1850 por Tarancón, por Belmonte de 1850 a 1851 y otra vez por Tarancón de 1851 a 1852. Gregorio Muñoz, otro hermano de Fernando Muñoz, ingresó en la recién restaurada Compañía de Jesús ${ }^{83}$; el afán de Fernando por querer formar un grupo fuerte y cohesionado en la corte, con influencia política, le llevó a proponerle como diputado en Cortes, lo que no pudo efectuarse debido a su condición de jesuita ${ }^{84}$, pero consiguió ser nombrado caballero de la orden de Santiago y obtuvo también la gran cruz de Isabel la Católica, Jesús Muñoz ${ }^{85}$, Marqués de Remisa, otro hermano de Fernando Muñoz ${ }^{86}$, fue Diputado por Pastrana ${ }^{87}$ en las legislaturas de “1846 al 50", y en las de 1850 a 1852 por Huete, finalmente, por Tarancón de 1853 a 1858. Joaquín Fontán ${ }^{88}$, yerno de José Antonio Muñoz ${ }^{89}$, casado con su hija Joaquina, era bibliotecario segundo de la Real Casa y diputado en Cortes. José Fulgosio ${ }^{90}$, marido de Alejandra Muñoz ${ }^{91}$, hermana de Fernando Muñoz, fue nombrado gentil hombre de cámara el 19 marzo 1847 y diputado por Sax (Alicante) de 1847 a 1849. Alfonso Chico de Guzmánn ${ }^{92}$ marido de Patricia, hija de José Antonio Muñoz, era abogado de los

José Güell y Renté, Paralelo entre Reinas Católicas, Doña Isabel I y Doña Isabel II (París: Imprenta de Jules Claye, 1858).

${ }^{80}$ Primer duque de Riánsares y de Montmorot, sino también miembro de la orden del Toisón de Oro, gran cruz de la Real y distinguida orden española de Carlos III, de la de San Genaro de Nápoles y de la Constantiniana de Parma, etc. AGP, Personal, caja 730, exp. 22.

81 Administrador del Real Sitio de Aranjuez (1834-1837), contador de la real Casa (1837) y apoderado general de la Infanta Luisa Fernanda, segundo conde del Retamoso, caballero gran cruz de la Real y distinguida orden española de Carlos III, caballero de la de Isabel la Católica y comendador de la Legión de Honor de Francia. El 30 de octubre de 1840 recibió la llave de gentil hombre de cámara. AGP, Personal, caja 731, exp. 1.

82 También fue Senador vitalicio (1851-1852), Archivo del Senado, ES. 28079.HIS-0370-01.

83 Catálogo de Jesuitas de la Provincia de España (Archivo de la Compañía de Jesús de Alcalá de Henares).

${ }^{84}$ Ángel Fernández de los Ríos, Luchas politicas en la España del siglo XIX (Madrid: English y Gras, 1880-1886), II, 186.

${ }^{85}$ AGP, Personal, caja 726, exp. 44.

${ }^{86}$ Fue nombrado caballero profeso de la orden de Calatrava, oficial de la Legión de Honor de Francia, gentil-hombre de Cámara con ejercicio, etc. Augusto de Burgos, Libro de oro de la nobleza. Reseña genealógica y descriptiva de la Casa Real, la grandeza de España y los títulos de Castilla (Madrid: Imprenta de Don Pedro Montero, 1859), parte I, t. V, 187-190.

${ }^{87}$ Fue senador vitalicio (1858-1860). Archivo Senado, ES.28079.HIS-0369-03.

88 Éste ejerció en algunas ocasiones de apoderado de Fernando Muñoz (AHPN, Referencia: 32010).

${ }^{89}$ Burgos, Libro de oro, parte I, T. V, 187-190.

90 AGP, Personal, caja 16933, exp. 21.

${ }^{91}$ La Camarera mayor participa que V.M. se ha servido conceder su Real permiso a Da Alejandra Muñoz para contraer matrimonio con el excelentísimo general D. José Fulgosio. Palacio 30 de octubre de 1846. Dese conocimiento a la Contaduría. AGP, Personal, caja 730, exp. 21.

${ }^{92}$ Fue nombrado caballero de la orden de Santiago. V. de Cadenas y Vicent, Caballeros de la Orden de Santiago que efectuaron sus pruebas de ingreso durante el siglo XIX (Madrid: Hidalguía, 1993), 483. 
tribunales nacionales y diputado ${ }^{93}$ por Belmonte de 1851 a 1854. Ángel Juan Álvarez ${ }^{94}$ (Palemón como firma las cartas que enviaba a Fernando Muñoz), amigo íntimo de Muñoz, fue diputado por Rioseco (Valladolid) en la legislatura de 1851 a 1852. Juan González Cabo-Reluz ${ }^{95}$, alcanzó el cargo de senador ${ }^{96}$ por Cuenca para la legislatura de 1844, reemplazando a los que salieron por la primera renovación, de los que en la anterior fueron declarados sujetos a reelección, y de los que habían renunciado. Joaquín María Cezar, amigo de Fernando Muñoz ${ }^{97}$, natural de Tarancón, fue procurador por Cuenca en las legislaturas de 1835 a 1836 y diputado a Cortes por Cuenca las legislaturas de 1837 a 1839. Una gran lista de personajes y diputados podría añadir (pero que me lo impide el espacio del que dispongo) que aún demostraría mejor el control que la familia real (y más concretamente, Fernando Muñoz) tenía sobre el Partido Moderado.

\section{c) El papel de los brokers: Diputaciones y cargos provinciales}

El patronazgo que Fernando Muñoz y su grupo de políticos moderados pudieran ejercer en la nación desde Madrid resultaría escasamente significativo si no hubieran contado con una figura como el bróker, ya que, si el sistema de patronazgo se basaba en las relaciones personales, las relaciones de un patrón con sus clientes resultaban muy limitadas en número. Los brókers potenciaban estas relaciones ya que era el intermediario entre el patrón y los clientes de una ciudad, región o empresa. El bróker se comportaba como un auténtico patrón dentro de su territorio defendiendo a sus clientes, ofreciéndoles sus servicios y orientando su opinión sobre los candidatos en las elecciones. Para ser bróker de una comarca o provincia debía de gozar prestigio y poder reconocido por la sociedad de su entorno y, sin duda, tener un político como patrón en la corte resultaba esencial para aparentar su gran influencia. Nos encontramos personajes que tenían poder en la máxima expresión de esta realidad con numerosas coincidencias que se congregaban a través de estrechas redes sociales ${ }^{98}$. Una vez introducidos como diputados o senadores (dentro del Partido Moderado),

${ }^{93}$ Senador vitalicio por Murcia (1871-1897), Archivo Senado, ES. 28079. HIS-0138-06.

${ }^{94}$ Nombrado en 1847 gentilhombre de cámara, oficial primero de cámara y Real Estampilla. AGP, Personal, caja 1329, exp. 63.

95 Natural de Tarancón y primo de Marcos Aniano (primo de Fernando Muñoz que ofició el casamiento secreto entre éste y SM la Reina María Cristina de Borbón. AGP, Personal, caja 458, exp. 44. Preceptor de S.M. y A.R. hasta el 10 de octubre de 1840, fecha en la que se jubiló. AGP, Personal, caja 462, exp. 13.

96 Archivo del Senado ES. 28079. HIS-0198-07.

${ }^{97}$ Carta de Paz Vega de Cézar, mujer de Joaquín María a Fernando Muñoz, fechada en Tarancón, 10 febrero 1845 (AHN, Diversos-títulos_familias, 3398, leg. 110, exp. 1).

${ }^{98}$ José Varela Ortega (dir.), El poder de la influencia. Geografía del caciquismo en España (1875-1923) (Madrid: Marcial Pons, 2001). Pedro Carasa Soto, "El poder local en la España contemporánea", Hispania 201 (1999): 12-25. 
establecían su red clientelar a las diputaciones o administraciones ${ }^{99}$ de éstas donde proponían sus candidatos afines con el fin de allanar el camino de los negocios en las provincias donde se realizaban infraestructuras estatales.

Fernando Muñoz tomaba decisiones, elegía colaboradores, supervisaba los nombramientos y escribía incansablemente cartas y respondía a las muchas que le enviaban. María Cristina suministraba el elemento simbólico y de poder; pero Muñoz, hombre del pueblo, tenía intuición para escoger los personajes adecuados que podían servir de bróker y lo que se podía exigir a cada uno de ellos. De ahí que tuviera especial atención en elegir a los presidentes de diputaciones y administradores provinciales ${ }^{100}$, lo que le permitía controlar después la realización de carreteras, ferrocarriles y otros negocios que se hacían en las provincias y que eran asignadas al duque de Riánsares o amigos ${ }^{101}$. La relación de casos en los que Fernando Muñoz intervino para que sus clientes ocupasen cargos en las diputaciones provinciales resulta muy larga, valga como ejemplo ${ }^{102}$, Eugenio de Corcuera, hombre de confianza de Muñoz y su familia ${ }^{103}$, se le nombró teniente de alcalde del ayuntamiento constitucional de Madrid ${ }^{104}$. Timoteo Cañete Parada, familiar de Fernando Muñoz, fue nombrado de Real Orden recaudador depositario y administrador de estancadas del Partido de Huete ${ }^{105}$. A su primo, Pascual Navacerrada, se le otorga el cargo de administrador en Tarancón ${ }^{106}$. Lorenzo Añover,

${ }^{99}$ Sirva como ejemplo la carta de Bravo Murillo al Duque de Riánsares, en la que le comunica que su primo ya ha sido nombrado administrador en Tarancón (AHN, Diversos-títulos_familias, 3415, leg. 152, exp. 1).

100 Esto se puede observar en la carta de Miguel M${ }^{a}$ Fuentes al conde de Retamoso: "Toledo 2 de Agosto 1853", AHN, Diversos títulos_familias, 3575, leg. 43, exp. 9. Para un estudio en profundidad de estas relaciones: José Antonio Inarejos Muñoz, Ciudadanos, propietarios y electores en la construcción del liberalismo español. El caso de las provincias manchegas (1854-1868) (Madrid: Biblioteca Nueva, 2008).

101 "Bilbao, 12 julio de 1851. El diputado general de Vizcaya Allen de Salazar, el diputado general de Vizcaya... de Hormachea, el alcalde y presidente de ayuntamiento de Bilbao Eulogio Larrincoya, El vicepresidente de la junta de comercio Gabriel de Ibarra". AHN, Diversos títulos_familias, 3419, leg. 165, exp. 1. Sobre el tema, Telesforo-Marcial Hernández Sempere, Ferrocarriles y capitalismo en el País valenciano, 1843-1879 (Valencia: Ayuntamiento Valencia, 1983). Id., "Los inicios de las concesiones ferroviarias en España”, en Homenaje al Dr. D. Juan Reglá y Campistol, ed. Roberto Calvo Sanz (Valencia: Imp. Fermar 1975), 2:287-302. Manuel González Portilla et al., Ferrocarriles y desarrollo (Red y mercados en el País Vasco, 1856-1914) (Bilbao: Universidad País Vasco, 1995).

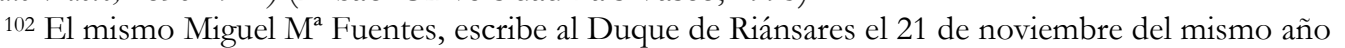
(AHN, Diversos títulos_familias, 3575, leg. 43, exp. 9).

103 AHPN, Referencia: 25020. AHPN, Referencia: 25020.

${ }^{104}$ Luis Sartorius. 28 de diciembre de 1847. AHN, Diversos títulos_familias, 3407, leg. 135, exp. 1. En esta época Eugenio de Corcuera era regidor del ayuntamiento de Madrid, Guía de Forasteros de 1847 (Madrid: Imprenta Nacional, 1847), 293. Expediente de Eugenio de Corcuera en AHN, Estado, leg. 7222.

105 AHN, Diversos títulos_familias, 3398, leg. 110, exp. 1.

106 “Excmo. Sr. duque de Riánsares, Mi muy estimado amigo; tengo el gusto de remitir a V el nombramiento de D. Pascual de Navacerrada por la administración de Tarancón, hecho por el Director, pues no es de provisión del ministerio. Sírvase $\mathrm{V}$ advertir al interesado que pida su retirada o licencia absolutas, si ya no la ha hecho con algún día de antelación a la fecha de su nombramiento pues si apareciera esto hecho siendo oficial del ejército y sin consultar al ministro de la Guerra, podría este oponer alguna dificultad. Juan Bravo Murillo”. AHN, Diversos títulos_familias, 3415, leg. 152, exp. 1. Asimismo, Fernando Muñoz apadrinó también a los dos hermanos de Camilo introduciéndoles en la 
fue nombrado por intermediación del Duque de Riánsares vocal del consejo de la ciudad de Cuenca ${ }^{107}$, etc. Todos estos personajes no sólo controlaban los negocios, sino también las elecciones a diputados provinciales. La influencia de nombramientos de Muñoz no se ceñía sólo al ámbito nacional, sino que también se extendía a instituciones estatales internacionales. El 29 enero de 1844, antes de asentarse de nuevo en Madrid, el duque de Riánsares escribía a Ramón María Narváez para que nombrase embajador de Roma a José Castillo y Ayensa y embajador de Lisboa al Conde de Colombí1 ${ }^{108}$.

\section{REDES EN LOS NEGOCIOS. LOS RECURSOS ECONÓMICOS DE FERNANDO MUÑOZ}

Tras la regencia de Espartero y una vez que los moderados consiguieron el poder (1844), la situación de María Cristina y Fernando Muñoz apareció como inexpugnable desde el punto de vista simbólico, sin que nadie se atreviera a someterlos a crítica. El control que establecieron sobre la prensa y la marginación de las Cortes en sus tareas de control a la Regente sirvieron para impedir toda crítica o censura de la posición progresista. De manera que Muñoz pudo emprender negocios de gran envergadura, empleando el nombre y el dinero de la Reina Madre, y contando con información privilegiada, connivencia del gobierno e impunidad cuando tuviera que transgredir los límites de la ley o la moral.

Dado su origen humilde y los numerosos hijos que tuvo en su matrimonio, Muñoz y María Cristina se esforzaron por dignificar la condición de los parientes y allegados que el propio Fernando Muñoz traía de su etapa anterior, y prepararse una seguridad financiera para sus hijos. Los negocios que emprendió Muñoz siempre se realizaron en asociación con otros personajes de su entorno, de los que cabía esperar apoyo y protección para asegurar el éxito de la operación y evitar que fuera objeto de ataques de ningún tipo. Pero para participar en estas grandes inversiones, ¿de dónde obtenía Fernando Muñoz recursos sustanciosos para poder asociarse con banqueros

administración de los sitios reales: Antonio Navacerrada, como visitador general del patrimonio real: AGP, Personal, caja 734, exp. 31, y, Camilo Navacerrada como administrador del Real Sitio del Pardo, AGP, Personal, caja 734, exp. 32.

107 “Sr. Duque de Riánsares. Cuenca 8 de mayo de 1865. Muy Sr. mío y de toda mi consideración, Su majestad la reina se ha servido nombrarme vocal del consejo provincial de esta ciudad; por la mediación de mi amigo D. Tomas Domínguez, representante en esta de su Casa, he sido repetidas veces recomendado a Valencia. Y por su mediación lo obtenido tan señalado cuanto inmerecido favor, esto quedará eternamente grabado en mi corazón y tendrá una gran satisfacción poder serle útil en esta o en cualquiera ora posición en que me hallo. Dios le conserve mil años y le de toda prosperidad que le desea este su agradecido... Lorenzo Añover”. AHN, Diversos títulos_familias, 3564, leg. 28, exp. 13.

108 París, 29 de enero de 1844. Carta de Fernando Muñoz a Ramón María Narváez. AHN, Diversos Títulos_Familias, 3390, leg. 93, exp. 7. 
tan importantes como Rothschild ${ }^{109}$ o Federico Huth ${ }^{110}$ ?

Dada la procedencia social de Fernando Muñoz y sus familiares, resulta imposible asociarse económicamente con los grandes banqueros que participaban en estos negocios de ultramar ${ }^{111}$, por lo que buscaba fondos en la asignación que las Cortes otorgaban a la Regente para su mantenimiento ${ }^{112}$ y también en el bolsillo "secreto" de la Reina. De ahí los numerosos debates parlamentarios para ensanchar las partidas asignadas a la Corona y la forma de cobrarlos:

Tocante a la asignación de V.M. es de opinión el Conde que deben asignarse a V.M. doce millones al año en vez de seis mas hay las dificultades que los demás ministros juzguen que la asignación de 40 millones para S.M la reina Isabel son demasiado para sus gasto, y quieren que de esta asignación salga la mayor parte de la de V.M. a lo cual se opone el Conde de Toreno y me encarga diga a V.M. reservadamente de reducir los gastos de S.M. la reina Isabel a 36 millones y 12 millones para V.M. de este modo sostener el presupuesto y allanar las dificultades que puedan presentarse; sin embargo nada hará hasta que V.M. me conteste sobre este particular cuanto sea de su real agrado. Además me ha añadido que del poco tiempo que está en el ministerio ha encargado 8 millones a la mayordomía, y aunque ha habido algunas equivocaciones se han allanado a su presencia, las cuales consistían en haber manifestado que alcanzaba 12 millones y aclarado, no resulta ser más que ocho; que puede estar V.M. segura que el Conde guardará los intereses de V.M. con toda consideración que es debida a su dignidad ${ }^{113}$.

\section{Inversiones en la Península}

El bloque fundamental de los negocios oscuros de Fernando Muñoz fue en las concesiones ferroviarias ${ }^{114}$. La década moderada fue la época de la introducción del ferrocarril en España. El gobierno Narváez fijó las reglas del juego mediante una orden ministerial de finales de 1844, que se mantuvo vigente hasta la Ley General de

\footnotetext{
109 Otazu y Llana, Los Rothschild, 103-109.

110 Con este banquero le unía una estrecha relación (no sólo económica) ya que como muestran algunas de las cartas que se intercambiaban, el duque de Riánsares le pedía consejo para dónde podía llevar a su hijo a estudiar (AHN, Diversos-títulos_familias, 3552, leg. 16, exp. 58).

111 Ángel Bahamonde y José Gregorio Cayuela Fernández, “Traficantes, armadores, y hacendados: elite colonial hispano-cubana y trasvase de capitales a finales del siglo XIX", Studia histórica. Historia contemporánea 15 (1997): 9-20; Miguel Ángel López Morell, La Casa Rothschild en España (1812-1941) (Madrid: Marcial Pons Historia, 2005), 65-105.

${ }^{112}$ Se puede ver en este extracto de carta de Serafín Valero, hijo del dómine de Tarancón y a quien Fernando Muñoz le colocó en el cargo de administrador del Real sitio de Vista Alegre y apoderado de los bienes de la infanta Luisa Fernanda. AGP, Personal, caja 1310, exp. 25. Como la dotación de las Cortes a SM la reina madre era una cuestión de negocios del propio "clan de Tarancón". "al fin pude ver a el directivo del Tesoro y me dijo que la asignación de S.M. se colocará en la Habana que sería por medio de orden para su pago; siendo al corriente las mensualidades de ahora y lo atrasado se pagaría después de cubiertas las obtenciones del momento [...] 27 de Enero de 1844". Archivo Histórico Nacional (en adelante AHN), Diversos-títulos_familias, 3390, leg. 93, exp. 7.

113 «Domingo Rochi. Madrid, 4 agosto de 1834». AHN, Diversos-títulos_familias, 3508, leg. 35.

114 Pro Ruiz, "Poder político y poder económico", 27-55, realiza una excelente síntesis, que sigo.
} 
Ferrocarriles de 1855, a pesar de tratarse de una disposición de rango legislativo menor, no discutida en Cortes ${ }^{115}$. En ella se renunciaba a que fuera el propio Estado el constructor de la red ferroviaria, dejando esta tarea en manos de promotores privados sometidos a un régimen de concesión administrativa. Las líneas Barcelona-Mataró, Madrid-Aranjuez-Alicante, Langreo-Gijón y Madrid-Cádiz, fueron concedidas entre 1843 y 1844. En los dos años siguientes se sancionaron hasta 25 líneas, con un total de 6.517 kilómetros concedidos, de los que sólo se construyeron efectivamente un 2,3 por 100 antes de que caducaran las concesiones. Los grupos concesionarios solían estar integrados por uno o varios empresarios extranjeros, en alianza con financieros, políticos y cortesanos españoles, aportando unos las conexiones para allegar capital y competencia técnica y otros las conexiones políticas para obtener la concesión y los privilegios administrativos o financieros que aseguraran la máxima ganancia ${ }^{116}$. Uno de los grupos más activos en este ámbito fue el aglutinado alrededor de José de Salamanca, controvertido personaje, a la vez especulador financiero y político de fortuna, que en un tiempo compartió inversiones y negocios con el general Narváez, y que llegó a ser ministro de Hacienda en 1847. Salamanca se hizo con la concesión de los ferrocarriles Madrid-Irún y Madrid-Alicante, después de que fracasaran en iniciar su construcción sendos grupos de promotores aglutinados por las diputaciones vascas —en el primer caso- y por la diputación de Alicante y la Junta de Comercio de la ciudad —en el segundo-, grupos ambos que también habían contado con conexiones directas en la Corte y en el gobierno (el abogado del proyecto alicantino fue Pedro José Pidal, ministro de Gobernación y uno de los hombres fuertes del Partido Moderado). Salamanca construyó (asociado al duque de Riánsares) el tramo de Madrid a Aranjuez, que fue la segunda línea de ferrocarril inaugurada en la España peninsular en 1851.

Pero no solo fue en los ferrocarriles, la red de negocios constituida en torno a la Corte y al poder moderado también participó en la canalización del río Ebro, concedida a una compañía de la que eran accionistas principales Grimaldi, el duque de Riánsares y su hermano, el conde de Retamoso. En el negocio de la reforma y dragado del puerto de Valencia, que como ya se mencionó fue concedido a Carriquiri en detrimento de otros grupos de la ciudad, fue igualmente objeto de escándalo, pues el contratista impuso condiciones excepcionalmente favorables para él, que el gobierno acabó admitiendo tras una intervención personal de la Reina.

Finalmente, no se ha de olvidar las obras realizadas en Madrid. Ciertamente, entre los grandes compradores de la desamortización en Madrid encontramos a algunos nombres relevantes de la política moderada, como Manuel Gaviria (que adquirió tres fincas, por valor de 362.000 reales), José de Salamanca (una finca de 2.000.005 reales), Andrés Borrego (una finca de 500.000 reales), Rufino García Carrasco (tres fincas, por 1.080.000 reales), José Gonzalo Vilches (una finca de 920.000 reales), o el alcalde de la ciudad en tiempos de Narváez, Manuel de Bárbara (quien compró una finca de 173.000 reales). Pero, en conjunto, la lista de compradores no

${ }^{115}$ Francisco Comín et al., 150 Años de Historia de los ferrocarriles españoles (Madrid: Fundación de los Ferrocarriles Españoles-Anaya, 1998), I, 29-54.

${ }^{116}$ Los datos los he tomado de Pro Ruiz, "Poder político y poder económico", 34-35. 
parece tener especial inclinación hacia el campo moderado, a falta de conocer la identidad política de gran parte de los nombres que en ella aparecen y — sobre todode saber algo más sobre el destino final de los bienes adquiridos por intermediarios y testaferros. Los negocios en Madrid estuvieron más relacionados, a partir de 1844, con las oportunidades de especulación y de construcción que abrió el propio proceso desamortizador. La desamortización ofreció edificios y solares urbanos en abundancia para instalar en ellos los cuarteles del nuevo Ejército nacional (monasterios de Nuestra Señora de Atocha y de San Jerónimo el Real, convento de San Francisco el Grande) y las dependencias de una Administración pública en expansión (monasterios de Montserrat y de las Salesas Reales, conventos del Espíritu Santo y de San Vicente de Paúl, colegio de Doña María de Aragón...); y permitió realizar demoliciones con las que emprender operaciones de reforma interior de la ciudad (Plaza de Oriente, Plaza de Santo Domingo...). A lo largo de la década moderada se inauguraron las nuevas sedes de los Ministerios de Hacienda (1845), Gobernación (1847), Guerra (1848), Fomento (1848) y Gracia y Justicia (1851), así como el Congreso de los Diputados (1849). Paralelamente, se levantaban en Madrid grandes edificios de valor representativo, vinculados de una u otra manera al patronazgo estatal, como fueron el Teatro Real (1850) o la Estación del Mediodía (1851). Y en 1851-1852 se inició el derribo por tramos de la «muralla» que rodeaba la ciudad desde el siglo XVII —en realidad una simple cerca con fines fiscales-, dando ocasión para nuevas edificaciones y revalorizaciones de suelo.

\section{Negocios en el Caribe}

La red establecida por Fernando Muñoz, no solo se ceñía al marco europeo, sino también se valió de las instituciones coloniales de Ultramar para ampliar su negocio. Cabe recordar que durante el reinado de Fernando VII ${ }^{117}$ se perdieron todas las colonias excepto Cuba, Puerto Rico y Filipinas. Durante la regencia de María Cristina, Cuba ${ }^{118}$ se convirtió en el principal núcleo de los negocios de la élite española ${ }^{119}$. Entre esta burguesía se incluía la familia Real española y en concreto, Fernando Muñoz y su "clan", que establecieron una sólida red, basándose en la estructura estatal establecida, desde donde controlaban todos los negocios de las islas. El marqués de Salamanca ${ }^{120}$, el marqués de Grimaldi, etc. se olvidaban del bajo pedigree de los Muñoz ante los rentables negocios que se preveían: Las minas de Mieres ${ }^{121}$ con

117 Emilio la Parra, Fernando VII: Un rey deseado y detestado (Barcelona: Tusquets, 2018), cap. 6.

118 Bahamonde y Cayuela Fernández, "Traficantes, armadores, y hacendados", 9-20. Id., "Entre la Habana, París y Madrid: intereses antillanos y trasvase de capitales de María Cristina de Borbón y el duque de Riánsares (1835-1873)", Estudios de historia social 44-47 (1988): 635-649.

${ }^{119}$ López Morell, La Casa Rothschild, 65-105. Id., "Los Rothschild en Latinoamérica en los siglos XIX y XX", en Origenes de la globalización bancaria: experiencias de España y América Latina (México: Colegio de México, 2017), 289-320.

120 AGP, Personal, caja 946, exp. 32.

${ }^{121}$ Era una empresa de Fernando Muñoz pero estaba dirigida por León Lillo y Grimaldi. Archivo Histórico Nacional de Protocolos Notariales (en adelante AHNP), Referencia: 32014. 
el marqués de Grimaldi, la línea de ferrocarril Madrid-Aranjuez se hizo entre el marqués de Salamanca ${ }^{122}$, marqués de Remisa (hermano de Fernando Muñoz) y Buchenton. En el negocio de las minas de azogue estaba implicado el conde de Toreno ${ }^{123}$. En Cuba, los negocios fueron realizados por la mayor parte de los miembros del clan de Tarancón.

La corrupción en las colonias españolas merece una amplia investigación, siguiendo los pasos que determinados historiadores han abierto hasta ahora ${ }^{124}$. Tras la independencia de las colonias americanas, la isla de Cuba fue el mercado en el que la burguesía española invirtió para hacer los grandes negocios ${ }^{125}$. Como afirma Candelaria Saiz, la articulación del movimiento de capitales a través de instituciones de crédito sólo fue una realidad a partir de la década de 1850 con la creación de la Real Caja de Descuentos, que poco después se transformó en el Banco Español de la Habana ${ }^{126}$. Hasta entonces, la principal fuente de financiación procedió de grupos de comerciantes suministradores de todo tipo de artículos ${ }^{127}$. El denominado banco de Fernando VII (creado el 25 diciembre 1827, pero comenzó a funcionar en 1832) se mantuvo al servicio de las de las operaciones financieras de la administración tributaria colonial, hábilmente manejada por "hombres fuertes" como el intendente Claudio Martínez Pinillos, conde de Villanueva ${ }^{128}$. No obstante, hasta su desaparición en 1840, el Banco se mostró incapaz de satisfacer las demandas financieras para la agricultura. Por su

122 "Madrid, 25 de abril de 1850. Ante mí el escribano de número de ella y los testigos, se constituyó personalmente el Excmo. Sr. D. Agustín Fernando Muñoz y Sánchez, Duque de Riansares y de Mormorot, procediendo de una parte; compareció también de otra parte el Excmo. Sr. D. José de Salamanca, ministro cesante de Hacienda, vecino de Madrid" (AHNP, Referencia: 25886).

123 Otazu y Llana, Los Rothschild, 64-94.

${ }^{124}$ María Candelaria Saiz Pastor, "La reestructuración del dominio español en Cuba. Poder Político y Hacienda colonial (1833-1838)", Estudios de Historia Social 44 (1988): 161-173. Bahamonde y Cayuela Fernández, "Entre la Habana, París", 635-649; Alfonso W. Quiroz, "Corrupción, burocracia colonial y veteranos separatistas en Cuba (1868-1910)", Revista de Indias 61 (2001): 91-111; Id., "Corrupción y hacienda colonial en Cuba, 1800-1868", en Las haciendas públicas en el Caribe hispano durante el siglo XIX, ed. Inés Roldán (Madrid: CSIC, 2008), 109-129; Xavier Huetz, L'Archipel des épices. La corruption de l'administration espagnole aux Philippines (fins XVIII-fins XIX siècle) (Madrid: Casa de Velázquez, 2006). Martín Rodrigo y Alexandre Coello de la Rosa (eds.), La justicia robada. Corrupción, codicia y bien público en el mundo hispánico (siglos XVII-XX) (Barcelona: Icaria, 2018).

125 Ana María Calavera Vaya, Relaciones bancarias hispano-cubanas: La Habana, plaza y mercado, 1829-186, Tesis Doctoral (UCM, 2015), t. 1, 73-79. J. Muñoz Pérez, "La conversión de Barcelona en el puerto de redistribución del azúcar cubano en el Mediterráneo", en Actes de les Segones Jornades d'Estudis CatalanoAmericans (Barcelona: Comissió Catalana del Cinquè Centenari del Descobriment d'Amèrica, 1987), 173192.

${ }^{126}$ María Candelaria Saiz Pastor, "La participación del sector financiero español en el negocio de la navegación trasatlántica (1827-1851)”, Historia Contemporánea 2 (1989): 103-118. José Ramón García López, "Banqueros y comerciantes-banqueros, clave oculta del funcionamiento del sistema bancario español del siglo XIX”, Moneda y Crédito 175 (1985): 59-85.

127 Saiz Pastor, "La participación”, 104. José Ramón García López, “Comerciantes-banqueros y casas de banca, eslabón perdido de la evolución del sistema bancario español”, Actas del IV Congreso de la Asociación de Historia Económica (1989): 61-67.

128 Prueba de ello es como el conde de Villanueva le da las gracias por la "influencia" ejercida por el duque de Riánsares para conseguir su nombramiento como Grande de España. Carta fechada en La Habana 8 de junio de 1844. AHN, Diversos títulos_familias, 3359, leg. 21, exp. 3. 
parte, la Intendencia de Hacienda de $\mathrm{Cuba}^{129}$, volcada desde 1830 en cubrir atenciones metropolitanas, utilizó exclusivamente este organismo para garantía de las operaciones que realizaba a las órdenes del gobierno de Madrid $^{130}$.

Fue en este período, justamente, tras la vuelta de María Cristina y Fernando Muñoz a Madrid, cuando el duque de Riánsares inició los negocios con Cuba, aprovechando esta falta de control institucional. Muñoz creó una tupida red de financieros, al margen de toda institución estatal, que le sirvió para enriquecerse y situarse en la alta burguesía nacional. El 9 de mayo de 1844, el superintendente de la isla, Pinillos, fue testigo de la instauración de este modelo de explotación colonial por parte de la burguesía española, siendo el gran valedor Fernando Muñoz ${ }^{131}$. El Duque tuvo muy claro desde el principio que para que sus negocios prosperasen en la isla debía contar con la ayuda del superintendente, por lo que lo atrajo a su influencia ${ }^{132}$. Es preciso recordar que la asignación regia que las Cortes españolas pagaban anualmente a la Monarquía se realizaba a través de las cuentas de la Habana ${ }^{133}$. Está cantidad económica fue motivo de especulación por parte de Fernando Muñoz y su "clan" para llevar a cabo sus negocios.

A través de la numerosa correspondencia, fruto de los negocios realizados, se pone de manifiesto la red de personajes que participaban en los negocios de la colonia con Muñoz, los agentes que tenían y las cantidades a que ascendía su participación. Uno de estos personajes era Joaquín Arrieta, como se desprende de la carta, fechada en La Habana el 7 de agosto de 1844, que el conde de Villanueva escribió a Muñoz ${ }^{134}$. Otro personaje fundamental de la red fue Antonio Parejo, hasta el punto de que Villanueva afirmaba al duque de Riánsares que ponía a disposición de Parejo "todo lo que permiten mis facultades". Sobre este personaje, el conde de Villanueva puso su intención de restablecer el banco de Fernando VII en la Isla, a la par que le informa de los negocios de ciertas minas ${ }^{135}$. Asimismo, el contador de las reales loterías de la Habana era otro cliente de Muñoz ${ }^{136}$.

${ }^{129}$ María Candelaria Saiz Pastor, "La revolución liberal española y el control de la hacienda cubana (1826-1843)", Revista de Historia Económica, Journal of Iberian and Latin American Economic History 9 (1991): 341-360. Calavera Vaya, Relaciones bancarias hispano-cubanas, 171-177.

130 María Candelaria Saiz Pastor, Liberales y Esclavistas. El dominio Colonial español en Cuba (1833-1868), Tesis doctoral (Universidad de Alicante, 1990), 77-123.

${ }^{131}$ Este control de la isla llevó a Fernando Muñoz a la intención de crear un banco en Cuba con hombres de valiosa reputación e influencia como así muestra la Carta de Antonio Juan Parejo al Duque de Riánsares: AHN, Diversos títulos_familias, 3539, leg. 3, exp. 42.

132 Fernando Muñoz, Madrid, 5 de abril de 1848. AHN, Diversos títulos_familias, 3406, leg. 133, exp. 2.

${ }^{133}$ Carta del conde de Villanueva a Fernando Muñoz, La Habana, 9 de mayo de 1844 (AHN, Diversos títulos_familias, 3359, leg. 21, exp. 3).

134 AHN, Diversos títulos_familias, 3359, leg. 21, exp. 3.

135 AHN, Diversos títulos_familias, 3359, leg. 21, exp. 3. Habana 7 de junio de 1844: "El conde de Villanueva como Superintendente general de Real hacienda de la Isla de Cuba, desea contratar un empréstito por un millón de pesos, a fin de restablecer el Banco de Fernando VII y auxiliar con estos fondos a los empresarios agrícolas, fabriles y comerciales cuyos resultados deben ser sumamente favorables a la riqueza pública” (AHN, Diversos títulos_familias, 3359, leg. 21, exp. 3).

136 AHN, Diversos títulos_familias, 3398, leg. 110, exp. 1. 
Las amistades de Muñoz y su familia, con los ejes principales de la administración económica de la Isla (intendente y Lotería) no terminaban ahí. Su hermano José Antonio, también tenía relación y negocios con el fiscal de hacienda de Cuba, que ostentó el cargo desde 1833 hasta 1846, Vicente Vázquez Queipo, sobrino del conde de Toreno ${ }^{137}$. A ellos se unió Juan Ortega ${ }^{138}$, alcaide del Palacio Real de 1847 a 1852, cargo que el propio Ortega había solicitado al duque de Riansares ${ }^{139}$, y fundaron una sociedad minera en Manila. Resulta sorprendente que "le dan y confieren su poder general, especial y amplio y bastante al Sr. D. Ramón Somoza, deán de la catedral de Manila" "140. Así mismo, Miguel López Acevedo aparece como otro gran bróker de Fernando Muñoz en Puerto Rico. Mientras, el intendente de la Isla, Manuel Núñez, dimitió de su cargo por discrepancias con el capitán general de la Isla, Juan de la Pezuela, se nombró para sustituirlo a Miguel López Acevedo. El nombramiento de este nuevo intendente no es casual, ya que tuvo una estrecha relación con Fernando Muñoz. Prueba de ello, fue el escrito de Fermín Caballero, La cuestión de la Regencia y el Casamiento de María Cristina de Borbón, en el que hacía referencia a las relaciones sociales del Duque de Riansares a su llegada a la corte:

Todas sus relaciones en la corte se reducían al marqués de Herrera, al escribiente del consulado, D. Miguel López Acevedo (cuya mujer cortejaba cuando era simple guardia) y al clérigo Marcos Aniano González, su paisano, que estaba accidentalmente en Madrid ${ }^{141}$.

Pero no parece que fuera una amistad superficial, ya que fue testigo en su boda de Fernando con la Reina celebrada el 28 de diciembre de 1833, oficiada por el entonces desconocido Marcos Aniano ${ }^{142}$. De hecho, antes de ser nombrado intendente de hacienda de la isla de Puerto Rico, fue director de la casa de la Moneda y el 5 de octubre de 1839 fue nombrado Gentil hombre de Cámara ${ }^{143}$.

\footnotetext{
137 Adolfo de Abel Vilela, "Vicente Vázquez Quiroga y Queipo de Llano", Diccionario Biográfico electrónico de la Real Academia de la Historia: http://dbe.rah.es/biografias/5030/vicente-vazquez-quirogay-queipo-de-llano.

138 AGP, Personal, caja 766, exp. 43. Alcaide de Palacio y gentil hombre de cámara. 27 de febrero de 1847 le nombra la reina Isabel II alcaide de palacio por fallecimiento de Francisco Carlos de Cáceres. Teniente de Alcaide del Real Palacio en real orden del 26 de julio de 1846. Fue nombrado en la misma fecha gentil hombre de Entrada. En febrero siguiente año, juró la plaza y el 29 de septiembre fue agraciado con la llave de gentil hombre. Fue coronel graduado. En 1852 se suprime el destino Alcaide principal consagrando sus servicios en otro punto.

${ }^{139}$ Madrid, 14 de septiembre de 1844. AHN, Diversos títulos_familias, 3538, leg. 2, exp. 30.

140 AHPN, Referencia: 25893.

${ }^{141}$ Caballero, La cuestión de la Regencia, 15.

142 Ibídem, 5. "El día 28 á las siete de la mañana, se verificó el matrimonio morganático entre doña María Cristina Borbón y D. Fernando Muñoz, siendo ministro del sacramento, el presbítero don Marcos Aniano González, y testigos el marqués de Herrera y D. Miguel López de Acevedo, y haciendo de asistente el presbítero don Acisclo Ballesteros".

143 AGP, Personal, caja 559, exp. 15. Birgit Sonesson en su libro La real hacienda en Puerto Rico: administración, política y grupos de presión (1815-1868) (Madrid: Instituto de Cooperación Iberoamericana, 1990), 125-126, amplía de manera muy detallada el currículum de este personaje y sus actividades.
} 
Toda esta red de negocios estaba conectada con la que había establecida en la península, que vigilaba de cerca el propio Fernando Muñoz y su hermano, según confiesa Antonio Parejo, "con tu influjo y buenas relaciones en la Corte a fin de alcanzar el resultado que nos prometemos ${ }^{144 \prime}$. Esta hegemonía y control de la isla se vio alterada en 1849 cuando en una carta se le informa al Duque que la real orden no ha sido realizada porque una persona con influjo en la isla así lo ha querido ${ }^{145}$. En 1851 se jubiló el conde de Villanueva, valedor de los negocios y del control de Fernando Muñoz en la Isla. El duque se dio cuenta de la importante figura y poder que suponía tener tan estrecha relación con el intendente de la isla, por lo que en 1851 no dudo en escribir a Juan Bravo Murillo para ver si podía colocar en su lugar a alguien de su conveniencia ${ }^{146}$.

La influencia de Fernando Muñoz también se extendía a los cargos eclesiásticos. El deanato de la Habana había estado ocupado por Marcos Aniano (el familiar de Fernando Muñoz que ofició su boda con María Cristina) hasta su jubilación, si bien, durante la regencia de Espartero (1841-1843) se le apartó de sus obligaciones como deán, como sucedió con el resto de miembros del "clan de Tarancón". Fernando Muñoz utilizó este cargo eclesiástico ${ }^{147}$ para que sirviera como "conducto" y así poder traspasar a la isla dinero procedente de sus negocios a tenor de lo que se refleja en las cartas que se intercambia el Duque con su socio y amigo Federico Huth y en donde hacía especial hincapié en el cargo que ostentaba Aniano en dicha Isla. La primera carta, aunque no la única, estaba fechada enParís, a 17 septiembre 1841:

Creo de merecer a V. tenga la bondad de presentar al cobro las dos adjuntas letras una de 202.005.2 libras dadas por Drake de la Habana contra sociedad Demdan de esa plaza y otra de 202 de Mr. Moger contra Richards Little and $C^{a}$ y espero que realizadas que sean de acuerdo gusto. Siguiendo a D. Marcos González deán de la Habana quien usted ya conoce, tomándolo como conducto ${ }^{148}$.

\section{CONCLUSIÓN}

Las revoluciones burguesas habían suprimido el sistema estamental y crearon una organización estatal basada en la soberanía nacional. Frente al "sistema cortesano"

${ }^{144}$ La Habana, 9 de junio de 1847, "Mi Sr. Fernando: Hoy sale para Madrid Lorenzo Arrieta, hijo y albacea testamentario de nuestro difunto amigo Joaquín Arrieta, [...] Te lo recomiendo pues mi eficazmente como joven muy acreedor a cualquiera atención que tengas a bien dispensarle y te ruego que tanto en el objeto que lleva, como en todos asuntos míos en particular que he confiado a su cuidado te sirva ayudarlo con tu influjo y buenas relaciones en la Corte a fin de alcanzar el resultado que nos prometemos. Antonio Parejo". AHN, Diversos títulos_familias, 3539, leg. 3, exp. 42.

145 Boulogne-sur-Mer, 6 de julio de 1849. AHN, Diversos títulos_familias, 3414, leg. 150, exp. 1.

146 Carta de J. Bravo Murillo. 1851. AHN, Diversos títulos_familias, 3543, leg. 7, exp. 9.

${ }^{147} \mathrm{El}$ control del deanato de la Habana preocupaba sobremanera a Muñoz y a María Cristina de Borbón, ya que como se puede observar en las contestaciones del presidente de ministros Juan Bravo Murillo a Fernando Muñoz el 22 de julio 1851 (AHN, Diversos títulos_familias, 3543, leg. 7, exp. 9 y AHN, Diversos títulos_familias, 3425, leg. 181, exp. 1).

148 París, 17 de septiembre de 1841. AHN, Diversos títulos_familias, 3359, leg. 21, exp. 3. 
que caracterizó la organización política de las Monarquías europeas durante la Edad Moderna, en el que el rey era la cabeza del reino y gobernaba una sociedad articulada por estamentos (privilegios), la estructura del Estado liberal había establecido unas instituciones basadas en la soberanía nacional de las que emanaban unas leyes que gobernaban una sociedad compuesta por individuos (todos iguales). Sin embargo, la realidad fue diferente, pues, el "sistema cortesano" no desapareció, siguió utilizándose en la práctica política mientras cambió la estructura del Estado y su justificación filosófica. La Corona consiguió mantener su influencia dentro del Estado liberal y, asimismo, por debajo de las instituciones del Estado se tejieron unas redes clientelares que posibilitaron la manipulación de la actuación de las instituciones (esto es, se actuaba de acuerdo al sistema cortesano), de esta manera, Fernando Muñoz y su familia consiguió cambiar de status social y constituirse en elite social. Esta forma de actuación es lo que consideramos "corrupción" ${ }^{149}$ en toda su propiedad. El estudio de los negocios de Fernando Muñoz y los modos de llevarlos a cabo nos ayuda a entender los grupos de poder que se formaron en el nuevo sistema y que han estructurado, en buen parte, la sociedad española, con sus élites de poder, durante el siglo XIX y parte del siglo XX.

\footnotetext{
${ }^{149}$ Sobre este tema valga citar los recientes estudios recopilados en Riquer et al. (eds.), La corrupción política en la España contemporánea.
} 


\section{REFERENCIAS BIBLIOGRÁFICAS}

Abel Vilela, Adolfo de, "Vicente Vázquez Quiroga y Queipo de Llano" en Diccionario Biográfico electrónico de la Real Academia de la Historia: http://dbe.rah.es/biografias/5030/vicente-vazquez-quiroga-y-queipo-de$\underline{\text { llano. }}$

Andújar, Francisco y Felices de la Fuente, María Mar (eds.), Elpoder del dinero. Venta de cargos y honores en el Antiguo Régimen (Madrid: Biblioteca Nueva, 2016).

Artola, Miguel y Flaquer Montequi, Rafael, La Constitución de 1812 (Madrid: Iustel, 2008).

Bahamonde, Ángel y Cayuela Fernández, José Gregorio, "Entre la Habana, París y Madrid: intereses antillanos y trasvase de capitales de María Cristina de Borbón y el duque de Riánsares (1835-1873)", Estudios de historia social 44-47 (1988): 635-649.

—, "Traficantes, armadores, y hacendados: elite colonial hispano-cubana y trasvase de capitales a finales del siglo XIX”, Studia histórica. Historia contemporánea 15 (1997): 9-20.

Baró Pazos, Juan, "Hacia la consolidación del régimen parlamentario en España: el Congreso de los Diputados en la Constitución de 1837”, Revista de Estudios Políticos 57 (1987): 57-106.

Benito, Vanesa; Garzón, Isabel; González, Juan Antonio y Mairal, María del Mar, "La Jefatura de Oficios y Aposentamiento de la Real Casa y Patrimonio (18141931)", Reales Sitios 174 (2007): 48-64.

Berle, Adolf y Means, Gardiner, The Modern Corporation and Private Property (New York: Transaction Publishers, 1933).

Boissevain, Jeremy, Friends of friend: networks, manipulators and coalitions (Oxford: Basil Brackwell 1978).

Bourdieu, Pierre, "Les juristes, gardiens de l'hypocrisie collective", en Normes juridiques et régulations sociale, eds. François Chazel y Jacques Commaille (Paris, LGDJ, 1991), 95-99.

Bots, Hans y Waquet, François, La Reppublica delle lettere (Bologna: Il Mulino, 2005).

Brough Macpherson, Crawford, La teoría politica del individualismo posesivo. De Hobbes a Locke (Madrid: Trotta, 1979). 
Buchan, Bruce y Hill, Lisa, An Intellectual History of political Corruption (London: PalgraveMacmillan, 2014).

Burdiel, Isabel, Los Borbones en pelota (Zaragoza: Institución Fernando el Católico, 2012).

—, "La revolución del pudor: escándalos, género y política en la crisis de la Monarquía liberal en España”, Historia y Política 39 (2018): 23-51.

Burgos, Augusto de, Libro de oro de la nobleza. Reseña genealógica y descriptiva de la Casa Real, la grandeza de España y los títulos de Castilla (Madrid: Imprenta de Don Pedro Montero, 1859).

Buxó de Abaigar, Joaquín, Domingo Dulce, General Isabelino. Vida y Época (Barcelona: Editorial Planeta, 1962).

Caballero, Fermín, La cuestión de la Regencia y el Casamiento de María Cristina de Borbón (Madrid: Imprenta del pueblo soberano, 1840).

Caballeros de la Orden de Santiago que efectuaron sus pruebas de ingreso durante el siglo XIX (Madrid: Hidalguía, 1993).

Calavera Vaya, Ana María, Relaciones bancarias hispano-cubanas: La Habana, plaza y mercado, 1829-186, Tesis Doctoral (UCM, 2015).

Cannadine, David, "Contexto, representación y significado del ritual: la monarquía británica y la intervención de la tradición, c. 1820-1977”, en La invención de la tradición, eds. Eric Hobsbawm y Terence Ranger (Barcelona: Crítica, 2002), 107-171.

Cánovas Sánchez, Francisco, El Partido Moderado (Madrid: Centro de Estudios Constitucionales, 1982).

Carasa Soto, Pedro, "El poder local en la España contemporánea”, Hispania 201 (1999): 12-25.

—, "De la burguesía a las elites, entre la ambigüedad y la renovación conceptual", Ayer 42 (2001): 213-239.

Casado, María Ángeles, "María Cristina de Borbón. Una regente cuestionada”, en La imagen del poder. Reyes y regentes en la España del siglo XIX, ed. Emilio La Parra (Madrid: Síntesis, 2001), 133-176. 
Casado, María Ángeles y Moreno, Mónica, "María Cristina de Borbón y María Cristina de Habsburgo: dos regentes entre los modos de vida aristocráticos y burgueses", Historia y Política 31 (2014): 113-138.

Chartier, Roger, Espacio público y desacralización en el siglo XVIII: los orígenes culturales de la revolución francesa (Barcelona: Gedisa, 1995).

Colección de Leyes Fundamentales, ed. de Sainz de Varanda (Zaragoza: 1957).

Colomer Viadel, Antonio, El sistema político de la Constitución española de 1837 (Madrid: Congreso de los Diputados, 1989).

Comín, Francisco; Martín Aceña, Pablo; Muñoz Rubio, Miguel y Vidal Olivares, Javier, 150 Años de Historia de los ferrocarriles españoles (Madrid: Fundación de los Ferrocarriles Españoles-Anaya, 1998).

Cos-Gayón, Fernando, Las cuentas de la Casa Real en el Estado. Breves apuntes (Madrid: Imprenta de Miguel Ginesta, 1873).

—, Historia jurídica del Patrimonio Real (Madrid: 1881).

Cruz, Jesús, "Lealtad y meritocracia: ambivalencias entre el discurso público y práctica privada de las elites ilustradas y liberales españolas", Historia social 23 (1995): 65-101.

Dalmau, Pol, "La reputación del notable. Escándalos y capital simbólico en la España liberal”, Historia y Politica 39 (2018): 79-107.

Dard, Olivier ; Engels, Jens Ivo ; Fahrmeir, Andreas y Monier, Frédéric (eds.), Scandales et corruption à l'époque contemporaine (Paris: Armand Colin, 2014).

Decretos del Rey don Fernando VII, por don Fermín Martín de Valmaseda (Madrid: en la Imprenta Real, 1818).

Díaz, Elías y Morodo, Raúl, “Tendencias y grupos políticos en las Cortes de Cádiz y en las de 1820", Cuadernos Hispanoamericanos 201 (1969): 637-675.

Eigen, Peter, Las redes de corrupción. La sociedad civil contra los abusos de poder (Barcelona: Ediciones del Bronce, 2004).

Eisenstadt, Shmuel Noah y Roniger, Louise, "Patron-Client Relations as a Model of Structuring Social Exchange", Studies in Society and History 16 (1980): 42-77.

Engels, Jens Ivo; Monier, Frédéric y Petiteau, Natalie, La politique vue d'en bas. Pratiques 
privées et débats publics, 19e-20e siècles (actes du colloque d'Avignon, mai 2010) (Paris: Armand Colin, 2012).

Engels, Jens Ivo, "De lo antiguo a lo nuevo. La historia de la corrupción política en Europa. Estado de la cuestión y debates actuales de investigación", en La corrupción política en la España Contemporánea, eds. Borja de Riquer, Joan Lluís Pérez Francesh, Gemma Rubí, Lluís Ferrán Toledano y Oriol Luján (Madrid: Marcial Pons, 2019), 25-46.

Farrales, Mark J., "What is Corruption? A History of Corruption Studies and the Great Definitions Debate", SSRN (2005): 1-50.

Fernández de los Ríos, Ángel, Luchas políticas en la España del siglo XIX (Madrid: English y Gras, 1880-1886).

Fernández García, Antonio, La Constitución de Cádiz (1812) y Discurso preliminar a la Constitución (Madrid: Castalia, 2002).

Flórez Estrada, Álvaro, La cuestión social (Madrid: Imprenta de Don Miguel de Burgos, 1839).

Forcadell i Esteller, Xavier, "La corrupción en los gobiernos y administraciones locales en la España Contemporánea", en La corrupción política en la España Contemporánea, eds. Borja de Riquer, Joan Lluís Pérez Francesh, Gemma Rubí, Lluís Ferrán Toledano y Oriol Luján (Madrid: Marcial Pons, 2019), 331-352.

Fradera, Josep María, Las burguesías europeas del siglo XIX: sociedad civil, política y cultura (Valencia: Biblioteca Nueva, Universitat de Valencia, 2000).

Frigo, Daniela, Il Padre di Famiglia. Governo della casa e governo civile nella tradirione dell'economica tra cinque e seicento (Roma: Bulzoni, 1985).

García López, José Ramón, "Banqueros y comerciantes-banqueros, clave oculta del funcionamiento del sistema bancario español del siglo XIX", Moneda y Crédito 175 (1985): 59-85.

—, "Comerciantes-banqueros y casas de banca, eslabón perdido de la evolución del sistema bancario español", Actas del IV Congreso de la Asociación de Historia Económica (1989): 61-67.

García Monerris, Carmen, "Fernando VII y el Real Patrimonio (1814-1820): las raíces de la cuestión patrimonial en el País Valenciano", Estudis d'Historia Contemporanea del Pais Valenciá 4 (1982): 35-66. 
García Monerris, Carmen y García Monerris, Encarna, "La nación y su dominio: el lugar de la corona", Historia Constitucional 5 (2004): 161-190.

—, Las cosas del rey. Historia política de una desavenencia (1808-1874) (Madrid: Akal, 2015).

Garrido Muro, Luis, Guerra y Paz: Espartero durante la Regencia de Maria Cristina de Borbón. (Madrid: Centro de Estudios Políticos y Constitucionales, 2016).

Gómez Ochoa, Fidel, "El liberalismo conservador español del siglo XIX, la formación de una identidad política, 1810-1840”, Historia y Política 17 (2007): 37-68.

Gómez Mendoza, Antonio, Ferrocarril, Industria y mercado en la modernización de España (Madrid: Espasa Calpe, 1989).

González Portilla, Manuel; Montero, Manuel; Garmendia, José María et al., Ferrocarriles y desarrollo (Red y mercados en el País Vasco, 1856-1914) (Bilbao: Universidad del País Vasco, 1995).

Goodman, Dena, The Republic of the Letters. A Cultural History of the French Enlightenment (Ithaca, New York: Cornell University Press, 1994).

Güell y Renté, José, Paralelo entre Reinas Católicas, Doña Isabel I y Doña Isabel II (París: Imprenta de Jules Claye, 1858).

Guereña, Jean-Louis, "La sociabilidad en la España contemporánea", en Sociabilidad fin de siglo: espacios asociativos en torno a 1898, eds. Rafael Villena Espinosa e Isidro Sánchez Sánchez (Cuenca: Universidad de Castilla La Mancha, 1999), 15-44.

Guia de Forasteros de 1847 (Madrid: Imprenta Nacional, 1847)

Gurtvich, Georges, Essais de sociologie: les formes de la sociabilité. Le problème de la conscience collective (Paris: Librairie du Recueil Sirey, 1938).

Habermas, Jürgen, Historia y crítica de la opinión pública, la transformación estructural de la vida pública (Barcelona: Gustavo Gili, 1981).

Hernández Sempere, Telesforo-Marcial, "Los inicios de las concesiones ferroviarias en España", en Homenaje al Dr. D. Juan Reglá y Campistol, ed. Roberto Calvo Sanz (Valencia: Imp. Fermar, 1975), 2:287-302.

—, Ferrocarriles y capitalismo en el País valenciano, 1843-1879 (Valencia: Ayuntamiento de Valencia, 1983).

Hespanha, Antonio M., La gracia del Derecho. Economía de la cultura en la Edad Moderna 
(Madrid: Centro de Estudios Constitucionales, 1993).

Huetz, Xavier, L'Archipel des épices. La corruption de l'administration espagnole aux Pbilippines (fins XVIII-fins XIX siècle) (Madrid: Casa de Velázquez, 2006).

Inarejos Muñoz, José Antonio, Ciudadanos, propietarios y electores en la construcción del liberalismo español. El caso de las provincias manchegas (1854-1868) (Madrid: Biblioteca Nueva, 2008).

Israel, Jonathan, La Ilustración radical. La filosofía y la construcción de la modernidad, 16501750 (México: FCE, 2012).

Jacob, Margaret C., The Radical Enlightenment: Pantheists, Freemasons and Republicans (London: Allen \& Unwin, 1981).

Jiménez Landi, Antonio, Esos días (Madrid: Aguilar, 1965).

Kaufman, Robert, "The Patron-Client concept and Macro politics: prospects and problems", Comparative Studies in Society and History 16 (1974): 284-308.

Koselleck, Reinhart, Crítica y crisis del mundo burgués (Madrid: Trotta, 1965).

Labra Cadrana, Rafael María, El Ateneo de Madrid: sus origenes-desenvolvimiento, representación y provenir (Madrid: Imprenta Aurelio Alaria, 1878).

Levi, Giovanni, "Prólogo: familias, jerarquización y movilidad social. Nuevas perspectivas", en Familias, jerarquización y movilidad social (Murcia: Universidad de Murcia, 2010), 9-19.

Leiva Ponce, Pilar y Andújar, Francisco (eds.), Mérito, venalidad y corrupción en España y América. Siglos XVII y XVIII (Valencia: Albatros, 2016).

López Morell, Miguel Ángel, Capital extranjero y crecimiento económico, inversión y actividades financieras de la casa Rothschild, Tesis Doctoral (Universidad de Sevilla, 2002).

_, La Casa Rothschild en España (1812-1941) (Madrid: Marcial Pons Historia, 2005).

—, "Los Rothschild en Latinoamérica en los siglos XIX y XX", en Orígenes de la globalización bancaria: experiencias de España y América Latina (México: Colegio de México, 2017), 289-320.

López Tabar, Juan, Los famosos traidores. Los afrancesados durante la crisis del Antiguo Régimen (1808-1833) (Madrid: Biblioteca Nueva, 2001). 
López Vela, Roberto, "Una apología de Isabel II desde la familia real", en Crisis y descomposición del sistema cortesano, eds. José Martínez Millán y David Quiles Albero (Madrid: Polifemo, 2020), 503-528.

Luján, Oriol, "En reconnaissant la corruption. La dénonciation des pratiques immorales pendant la consolidation du système parlementaire espagnol (18341868)", en Dénoncer la corruption. Chevaliers blancs, pamphlétaires et prometeurs de la transparence à l'époque contemporaine, eds. Cesare Martina, Frédéric Monier, Olivier Dard y Jens Ivo Engels (Paris: Demopolis, 2018), 75-93.

Macfarlane, Kenneth Bruce, "Bastard feudalism", en England in the Fifteenth Century: Collected Essays of Kenneth Bruce Macfarlane (London: Hambledon Continuum, 1981), 23-43.

Marais, Jean-Luc, Les Sociètes d'hommes. Histoire d'une socialité du 18 siècle á nos jours, Anjou, Maine, Touraine (Vauchretien: Ivan Davy, 1986).

Marcuello Benedicto, Juan Ignacio, La práctica parlamentaria en el reinado de Isabel II (Madrid: Congreso de los Diputados, 1986).

—, "La práctica del poder moderador de la Corona en la época de Isabel II", Revista de Estudios Políticos 55 (1987): 197-236.

—, La Constitución de 1845 (Madrid: Iustel, 2007).

—, "El discurso constituyente y la y la legitimación de la Monarquía de Isabel II en la reforma política de 1845", en Culturas políticas monárquicas en la España liberal. Discursos, representaciones y prácticas (1808-1902) (Valencia: Universitat de Valencia, 2017), 151-176.

Marliani, Manuel, La Regencia de D. Baldomero Espartero y los sucesos que la prepararon (Madrid: Imprenta de Manuel Galiano, 1870).

Martínez Millán, José y Quiles Albero, David, "Introducción”, en Crisis y descomposición del sistema cortesano, eds. José Martínez Millán y David Quiles Albero (Madrid: Polifemo, 2020), 1-10.

Menéndez Rexach, Ángel, "La separación entre la casa del rey y la administración del Estado (1814-1820)", Revista de Estudios Políticos 55 (1987): 55-122.

Moral Roncal, Antonio Manuel, ;El enemigo en Palacio! Afrancesados, liberales y carlistas en la Real Casa y Patrimonio (1814-1843) (Madrid: Universidad de Alcalá de Henares, 2005). 
Mornier, Frédéric; Engels, Jens Ivo y Dard, Olivier (Coords.), Patronage et corruption politiques dans l'Europe Contemporaine (Paris: Armand Colin, 2014).

Moya Valgañón, José Gabriel, “El Patrimonio Nacional. Museos Vividos”, Arbor 665 (2001): 15-28.

Muñoz Pérez, J., "La conversión de Barcelona en el puerto de redistribución del azúcar cubano en el Mediterráneo", en Actes de les Segones Jornades d'Estudis CatalanoAmericans (Barcelona: Comissió Catalana del Cinquè Centenari del Descobriment d'Amèrica, 1987), 173-192.

Navarro Zamorano, Ruperto, Curso de Derecho natural de Abrens (Madrid: Boix, 1841).

Núñez-García, Víctor-Manuel, "Las élites en Palacio, la monarquía y la corrupción en la Corte Isabelina”, en Un Rey para la nación. Monarquía y nacionalización en el siglo XIX, ed. Raquel Sánchez (Madrid: Sílex, 2019), 283-311.

Orobón, Marie Angèle, "Una gloriosa revolución: prensa satírica ilustrada y afirmación militante (1868-1870)", en La historia, lost in translation? Actas del XIII Congreso de la Asociación de Historia Contemporánea, eds. Alberto González Madrid, Manuel Ortiz Heras y Juan Sisinio Pérez Garzón (Cuenca: Universidad de Castilla La Mancha, 2017), 1065-1075.

Parra, Emilio la, Fernando VII: Un rey deseado y detestado (Barcelona: Tusquets, 2018).

Pavía Dopazo, Naiara, "El uso del Exemplum histórico en el debate sobre la monarquía en las Cortes Constituyentes del Bienio Progresista", en El lenguaje politico y retórico de las constituciones españolas. Proyectos ideológicos e impacto mediático en el siglo XIX, eds. José Antonio Caballero López, José Miguel Delgado Idarreta y Rebeca Viguera Ruiz (Oviedo: Fundación P. Mateo Sagasta, 2015), 267-287.

Pérez Galdós, Benito, Bodas Reales (Madrid: Imprenta de S.M., 1900).

Peris y Valero, José, El proceso de los Borbones (Madrid: Imprenta de la Regeneración, 1856).

Pérez Núñez, Javier, "El alzamiento moderado-fuerista de octubre de 1841. El caso de la villa de Bilbao", Hispania 56 (1996): 565-586.

Pich, Josep, “La Gloriosa y la radicalización de la sátira. Tomás Padró, La Flaca y la cultura política republicana", en La historia, lost in translation? Actas del XIII Congreso de la Asociación de Historia Contemporánea, eds. Alberto González Madrid, Manuel Ortiz Heras y Juan Sisinio Pérez Garzón (Cuenca: Universidad de Castilla La Mancha, 2017), 1077-1089. 
Piqueras, José Antonio, "Negocios y política en el siglo XIX español", en Poder económico y poder politico, eds. Javier Paniagua y José Antonio Piqueras (Valencia: Centro Francisco Tomás y Valiente-UNED-Fundación Instituto Historia Social, 1998), 11-52.

Pro Ruiz, Juan, "Poder político y poder económico en Madrid de los moderados (18441854)", Ayer 66 (2007): 27-55.

—, "La formación de la clase política liberal en España (1833-1868)", en Historia Contemporánea 23 (2001): 445-481.

—, El Estatuto Realy la Constitución de 1837 (Madrid: Iustel, 2009), 12-59.

—, "El Estado grande de los Moderados en la España del siglo XIX", Historia y Política 36 (2016): 19-48.

Quiroz, Alfonso W., "Corrupción, burocracia colonial y veteranos separatistas en Cuba (1868-1910)", Revista de Indias 61 (2001): 91-111.

-, Corrupción y hacienda colonial en Cuba, 1800-1868", en Las haciendas públicas en el Caribe bispano durante el siglo XIX, ed. Inés Roldán (Madrid: CSIC, 2008), 109129.

Ramos Santana, Alberto, Constitución política de la Monarquía española, promulgada en Cádir. el 19 de marzo 1812, y Discurso preliminar leido en las Cortes al presentar la Comisión de Constitución el proyecto de ella (Cádiz: Servicio de Publicaciones Universidad de Cádiz, 2010).

Requena Santos, Félix, "El concepto de red social”, Reis: Revista española de investigaciones sociológicas 48 (1989): 137-152.

—, Amigos y redes sociales: elementos para una sociología de la amistad (Madrid: Siglo XXI, 1994).

Reinhard, Wolfgang (Coord.), Las elites de podery la construcción del Estado (México: FCE, 1996).

Ringrose, David, "Madrid capital imperial”, en Madrid. Historia de una capital, eds. Santos Juliá, David Ringrose y Cristina Segura (Madrid: Fundación Caja de Madrid, 1995).

Riquer, Borja de; Rubí, Gemma y Toledano, Lluís Ferrán, "Más allá del escándalo. La historia de la corrupción política en la España contemporánea”, en La corrupción 
política en la España Contemporánea, eds. Borja de Riquer, Joan Lluís Pérez Francesh, Gemma Rubí, Lluís Ferrán Toledano y Oriol Luján (Madrid: Marcial Pons, 2019), 47-80.

Roche, Daniel, Les Républicains des lettres: Gens de culture et lumières au XVIIIe siècle (Paris: Fayard, 1988).

Rodrigo, Martín y Coello de la Rosa, Alexandre (eds.), La justicia robada. Corrupción, codicia y bien público en el mundo bispánico (siglos XVII-XX) (Barcelona: Icaria, 2018).

Rubí, Gemma y Monier, Frédéric, "Presentación. Los favores y los sermones", Ayer 115 (2019): 13-21.

Rubí, Gemma y Toledano, Lluís Ferran, "La corrupción del siglo. Palabras y discursos sobre la corrupción política en la España del siglo XIX”, Ayer 115 (2019): 131157.

Sagra, Ramón de la, Lecciones de economía social dadas en el Ateneo cientifico de Madrid (Madrid: Imprenta de Ferrer y Compañía, 1840).

Sahuí, Alejandro, Razón y espacio público: Arendt, Habermas y Rawls (México: Coyoacán, 2002).

Saiz Pastor, María Candelaria, Liberales y Esclavistas. El dominio Colonial español en Cuba (1833-1868), Tesis doctoral (Universidad de Alicante, 1990), 77-123.

—, "La reestructuración del dominio español en Cuba. Poder Político y Hacienda colonial (1833-1838)", Estudios de Historia Social 44 (1988): 161-173.

-, "La participación del sector financiero español en el negocio de la navegación trasatlántica (1827-1851)”, Historia Contemporánea 2 (1989): 103-118.

—, "La revolución liberal española y el control de la hacienda cubana (1826-1843)", Revista de Historia Económica, Journal of Iberian and Latin American Economic History 9 (1991): 341-360.

Sanz Fernández, Jesús, La sargentada de la Granja. La Granja de San Ildefonso (Madrid: Icaro, 2012).

Solà y Gussinyer, Pere, “Asociacionismo en la España periférica: tipología y rasgos dominantes", en Asociacionismo en la España contemporánea, vertientes y análisis interdisciplinar, ed. Elena Maza Zorrilla (Valladolid: Universidad de Valladolid, 2003), 89-146. 
Suárez, Federico, Los sucesos de la Granja (Madrid: CSIC, 1953).

Terrón, Eloy, Sociedad e Ideología en los orígenes de la España Contemporánea (Barcelona: Península, 1969).

Thompson, John B., "Los escándalos sexuales en la esfera política" en El escándalo politico. Poder y visibilidad en la era de los medios de comunicación, eds. John B. Thompson (Barcelona: Paidós, 2001), 167-218.

Tortella Casares, Gabriel, Los orígenes del capitalismo de España: banca, industria y ferrocarriles en el siglo XIX (Madrid: Tecnos, 1973).

Urquijo Goitia, José Ramón, Gobierno y ministros españoles en la Edad Contemporánea (Madrid: CSIC 2008).

Varela Suances-Carpegna, Joaquín, "La Constitución de 1837: una Constitución transacional”, Revista de Derecho Público 20 (1983-1984): 95-106.

Veiga, Xosé, "Los marcos sociales del clientelismo político", Historia Social 34 (1999): $27-44$.

—, La Monarquia doceañista (1810-1837). Avatares, encomios y denuestos de una extraña forma de gobierno (Madrid: Marcial Pons, 2013).

Vilches, Jorge, Progreso y libertad. El partido Progresista en la revolución liberal española (Madrid: Alianza, 2001).

Villacorta Ramos, Francisco, El Ateneo Científico, Literario y Artístico de Madrid, 1885 1912 (Madrid: CSIC, 1985).

—, Profesionales y burócratas: estado y poder corporativo en la España del siglo XX (1890-1923) (Madrid: Siglo XXI, 1989).

—, "Los Ateneos liberales: política, cultura y sociabilidad intelectual", Hispania 63/2 (2003): 415-444.

Villarroya, Joaquín Tomás, El sistema politico del Estatuto Real (Madrid: Instituto de Estudios Políticos, 1968).

Varela Ortega, José (dir.), Elpoder de la influencia. Geografía del caciquismo en España (18751923) (Madrid: Marcial Pons, 2001).

Windler, Christian, "Mediando relaciones. Redes sociales y cambio político", Hispania 199 (1998): 575-605. 
Zozaya Montes, María, El casino de Madrid: ocio, sociabilidad, identidad y representación social, Tesis doctoral (UCM, 2008).

Zurita Aldeguer, Rafael, "La representación política en la formación del Estado español (1837-1890)", en Estado y periferias en la España del siglo XIX, ed. Salvador Calatayud Giner (Valencia: PUV, 2009), 159-183.

Recibido: 2 de septiembre de 2020

Aprobado: 11 de octubre de 2020 